\title{
Prevalence, Virulence, and Antibiotic Resistance of Vibrio parahaemolyticus from Seafood and its Environment: An Updated Review
}

\author{
Deniz Ürünleri ve Çevresinde Vibrio parahaemolyticus'un Yaygınlık, Virülans ve Antibiyotik \\ Direnç Profilleri: Güncel Bir Derleme
}

\author{
(D) Soibam NGASOTTER ${ }^{1}$, (D) Susmita MUKHERJEE ${ }^{2}$, (D) Soibam Khogen SINGH ${ }^{1}$, (D) Deeksha BHARTI ${ }^{3}$, (D) Ramjanul HAQUE ${ }^{3}$, \\ (D) Shubham VARSHNEY ${ }^{4}$, (D) Chinmay NANDA ${ }^{3}$, (D) David WAIKHOM ${ }^{1}$, (D) Manoharmayum Shaya DEVI ${ }^{5}$, (D) Asem Sanjit SINGH ${ }^{3}$ \\ ${ }^{1}$ College of Fisheries, Central Agricultural University (Imphal), Tripura, India \\ ${ }^{2}$ Faculty of Fishery Sciences, West Bengal University of Animal and Fishery Sciences (WBUAFS), Kolkata, India \\ 3ICAR-Central Institute of Fisheries Education (CIFE), Mumbai, India \\ ${ }^{4}$ Faculty of Biosciences and Aquaculture, Nord University, Bodø, Norway \\ 5 ICAR-Central Inland Fisheries Research Institute (CIFRI), Barrackpore, India
}

\section{Abstract}

Vibrio parahaemolyticus is a curved, rod-shaped, Gram-negative, halophilic bacterium that is widely disseminated in coastal, marine, and estuarine environments and causes acute gastroenteritis due to raw or undercooked seafood consumption, wound infection, and septicemia in humans. A wide variety of virulence factors, such as its toxins, type 3 secretion system, type 6 secretion system, adhesins, urea hydrolysis, and flagellar motility, are responsible for initiating infection and causing illness to the host. The pandemic clone emergence that causes global outbreaks is a major concern. Additionally, V. parahaemolyticus has emerged as a shrimp pathogen that causes acute hepatopancreatic necrosis disease or early mortality syndrome, which threatens the viability of the shrimp aquaculture industry. Moreover, the emergence of multidrug-resistant $V$. parahaemolyticus strains in seafood and environmental samples in recent years raises a serious concern of human health on seafood safety. This review highlights the prevalence of $V$. parahaemolyticus in various countries and newly emerging inland saline aquaculture areas, pathogenassociated seafood-borne outbreaks, and various virulence factors. Additionally, it provides updated literature on antibiotic resistance profiles of $V$. parahaemolyticus from seafood and environmental samples in recent years.

Keywords: Antibiotic resistance, prevalence, seafood, virulence, Vibrio parahaemolyticus

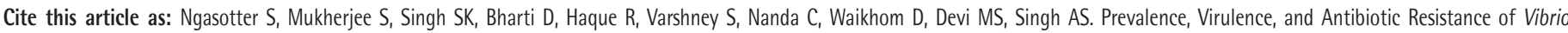
parahaemolyticus from Seafood and its Environment: An Updated Review. Mediterr J Infect Microb Antimicrob. 2022;11:1. 
Vibrio parahaemolyticus, kıyı, deniz ve nehir ağzı ortamlarında yaygın olarak görülen kavisli, çubuk şeklinde, Gram-olumsuz, halofilik bir bakteridir. İnsanlarda çiğ veya az pişmiş deniz ürünleri tüketimi, yara enfeksiyonu ve septisemi ile ilişkili akut gastroenterite neden olur. Toksinleri, tip 3 salgılama sistemi, tip 6 salgılama sistemi, adezinler, üre hidrolizi ve flagellar motilite gibi çok çeşitli virülans faktörleri, enfeksiyonu başlatmaktan ve konakçıda hastalığa neden olmaktan sorumludur. Küresel salgınlara neden olan pandemik klonların ortaya çıkması büyük bir endişe kaynağıdır. Ayrıca, V. parahaemolyticus, karides yetiştiriciliği endüstrisinin canlılığını tehdit eden akut hepatopankreatik nekroz hastalığı veya erken ölüm sendromuna neden olan bir karides patojeni olarak ortaya çıkmıştır. Ayrıca, son yıllarda deniz ürünleri ve çevresel örneklerde çoklu ilaca dirençli V. parahaemolyticus suşlarının ortaya çıkması, deniz ürünleri güvenliği konusunda insan sağlığı açısından ciddi bir endişe yaratmaktadır. Bu derleme, V. parahaemolyticus'un çeşitli ülkelerde ve yeni ortaya çıkan iç su balıklandırma alanlarındaki prevalansını, bu patojenle ilişkili deniz ürünleri kaynaklı salgınları ve enfeksiyonu başlatmaktan ve konakçıda hastalığa neden olmaktan sorumlu çeşitli virülans faktörlerini vurgulamaktadır. Ayrıca son yıllardaki, deniz ürünleri ve çevre örneklerinde $V$. parahaemolyticus'un antibiyotik direnç profilleri hakkında güncel literatür sunmaktadır. Anahtar Kelimeler: Antibiyotik direnci, yaygınlık, deniz ürünleri, virülans, Vibrio parahaemolyticus

\section{Introduction}

Over the decades, a significant contribution from aquaculturebased fish-food supply has taken place, whereas supply from capture fisheries is leveled out. In both cases, fish products are often associated with certain food safety issues, as the risk of chemical and biological agent contamination is greater in freshwater and coastal ecosystems than in the open seas. Largely, the associated food safety issues differ between regions and habitat of collection/harvest, apart from the management practices and environmental conditions. Therefore, proper assessment and regulation of any food safety concerns are becoming increasingly essential and indispensable. These days, the presence of pathogenic bacteria in marine habitats raises a big concern on food safety worldwide due to the inherent potentials of these microbial groups to cause disease outbreaks. Among the potential disease-causing hazards, Vibrio parahaemolyticus, a Gram-negative, halophilic bacterium, which is widely disseminated in estuarine, marine, and coastal surroundings, emerges as a very obvious human threat example $\mathrm{e}^{[1]}$. It is curved or rod-shaped and can grow at sodium chloride concentrations of 3-8\% with an optimum salt concentration of 2-4\%. $V$. parahaemolyticus is susceptible to the vibriostatic agent 0/129, a fermentative bacteria, motile, with a single polar flagellum. It is typically found in a free-swimming state or attached to inert and animate surfaces, including zooplankton, fish, shellfish, or any suspended matter underwater ${ }^{[2]}$. On thiosulfate citrate bile salt sucrose (TCBS) agar, $V$. parahaemolyticus is distinguished from other Vibrio species, such as Vibrio cholerae and Vibrio alginolyticus, by its sucrose non-fermenting characteristics and appear as green colored colonies $^{[3]}$. Vibrio vulnificus also appears as green-colored colonies on TCBS agar and differs from $V$. parahaemolyticus and other Vibrio species by its ability to ferment lactose ${ }^{[4]} . V$. parahaemolyticus is classified based on the antigenic properties of the somatic $(0)$ and capsular $(K)$ antigen produced in various environmental conditions ${ }^{[5,6]}$.
V. parahaemolyticus causes acute gastroenteritis in humans due to the consumption of contaminated raw or undercooked seafood with virulent strains ${ }^{[7,8]}$. It also causes infections through open wounds that are exposed to seawater and cause septicemia, wound infection, or ear infection that may be life-threatening to individuals with pre-existing medical conditions ${ }^{[9,10]}$. Apart from being a human pathogen, it is now considered an aquatic zoonotic pathogen that can cause vibriosis in many fish and shellfish species and is one of the pathogenic agents that threaten the viability of the aquaculture industry, especially shrimp ${ }^{[10,11]}$. $V$. parahaemolyticus that carry pirA and pirB toxin genes is the cause of acute hepatopancreatic necrosis disease (AHPND) or early mortality syndrome (EMS) in shrimp, which causes heavy losses in the shrimp industry ${ }^{[12]}$. AHPND was first reported in China in 2009, followed by Malaysia in 2010, Vietnam in 2011, Thailand in 2012, and Mexico in 2013 ${ }^{[11]}$. The mortality rate of shrimps due to AHPND is very high, reaching up to $100 \% \%^{[13]}$. Species of shrimps that are susceptible to $V$. parahaemolyticus are Litopenaeus vannamei, Penaeus monodon, and Penaeus chinensis ${ }^{[14]}$.

V. parahaemolyticus is a member of the indigenous flora of marine and brackish water environments and is detected in a wide variety of marine species, including eels, octopus, squid, sardines, tuna, mackerel, perch, flounder, rockfish, red snapper, pompano, etc. ${ }^{[15]}$. Additionally, it is most commonly found in bivalve mollusk and shellfish ${ }^{[16]}$. Lesmana et al. ${ }^{[17]}$ reported that warm summer months are considered peak periods for the isolation of this bacterium. Environmental factors for the prevalence and distribution of $V$. parahaemolyticus include water temperature, salinity, oxygen concentrations, plankton density, presence of sediment, organic matter in suspension, and marine organisms ${ }^{[18]}$. Earlier, few reviews on $V$. parahaemolyticus have described its virulence and outbreaks globally. However, these studies lack focus on the antibiotic resistance of the pathogen. Given the importance of its associated pathogenicity and food safety concerns, the recent works were updated with 
its prevalence in many countries and newly emerging inland saline aquaculture areas, recent reports on pathogen-related foodborne outbreaks, various virulence factors for host infection and illness, and antibiotic resistance profiles of this bacterium that is isolated from seafood and its culturing environments.

\section{Prevalence}

V. parahaemolyticus was first reported in Japan in 1950 in an outbreak of food poisoning case that caused 272 illnesses and 20 deaths ${ }^{[19]}$. The bacterium was isolated from victims of the epidemic in Japan and was found to be associated with the consumption of shirasu, a Japanese boiled and semi-dried sardine dish $^{[20]}$. Since then, $V$. parahaemolyticus has been commonly found to be prevalent in seafood samples in South East Asian countries $^{[21-23]}$. V. parahaemolyticus has accounted for several gastrointestinal disorder cases in Japan ${ }^{[20,24,25]}$, Taiwan ${ }^{[26,27]}$, China since the early $90^{\prime} \mathrm{s}^{[28-30]}, \operatorname{Laos}^{[31]}$, Bangladesh ${ }^{[32]}$, Hong Kong, and Indonesia ${ }^{[31,33]}$.

Yano et al. ${ }^{[34]}$ reported the prevalence of pathogenic V. parahaemolyticus in Thailand, which is one of the major producers and exporters of cultured shrimp worldwide. Pathogenic and antimicrobial-resistant $V$. parahaemolyticus was isolated from shrimps and cockles in Malaysia ${ }^{[35]}$. In India, V. parahaemolyticus was first isolated from fecal samples of patients with acute diarrhea admitted to the Johns Hopkins Unit of the Infectious Diseases Hospital, Calcutta ${ }^{[36]}$. A recent study isolated $V$. parahaemolyticus strains from patients with acute diarrhea who are admitted to Infectious Diseases Hospital, Kolkata, from 2001 to 2012 $2^{[37]}$. Reyhanath and Kutty ${ }^{[3]}$ have reported the prevalence of multidrug-resistant strains of $V$. parahaemolyticus from the fish landing center in Ponnani, South India. Narayanan et al. ${ }^{[39]}$ isolated pathogenic $V$. parahaemolyticus with high genetic diversity and carbapenam resistance from shrimp aquaculture farms in central Kerala, India. Yu et al. ${ }^{[26]}$ reported the prevalence of $V$. parahaemolyticus in oysters and clam culturing environments in Thailand. The isolated strains exhibited hemolytic or urease activities and the presence of gene markers for $t d h$, trh, type 3 secretion system T3SS1 (vcrD1), or T3SS2 $\alpha$ (vcrD2). Guin et al. ${ }^{[40]}$ reported a high prevalence of pathogenic $V$. parahaemolyticus in fish and water samples in and around Kolkata, India. The study also revealed the emergence of several new serovars of pandemic $V$. parahaemolyticus and was closely related to 03:K6 serovar (60$85 \%$ ) by pulsed-field gel electrophoresis analysis.

In Europe, V. parahaemolyticus has been isolated from the North Sea, the Mediterranean Sea, the Baltic Sea ${ }^{[1]]}$, and the Black Sea ${ }^{[42]}$. V. parahaemolyticus was found prevalent in 53 of 100 water samples in the coastal waters of Guadeloupe ${ }^{[43]}$. Outbreaks associated with $V$. parahaemolyticus infections are rarely reported in European countries compared to Asian countries. In 1999, a total of 64 illnesses were reported in three episodes due to the consumption of raw oysters from a typical outdoor street market in Galicia, Northwest Spain ${ }^{[44]}$. Robert-Pillot et al. ${ }^{[45]}$ reported the prevalence of pathogenic $V$. parahaemolyticus from environmental samples of French coastal areas and seafood products that were imported into France. In 2016, New Delhi metallo-beta-lactamase 1 producing V. parahaemolyticus strain was isolated from seafood samples imported from Vietnam to France ${ }^{[46]}$. In 2004, a V. parahaemolyticus outbreak of 80 illnesses occurred in A Coruña, Spain ${ }^{[4]}$. All patients had attended a wedding ceremony in the same restaurant. The epidemiologic investigation revealed that the outbreak was caused by the consumption of boiled crabs, which were prepared under unsanitary conditions. V. parahaemolyticus infections are usually rare and intermittent across all of Europe except Galicia in northwestern Spain. This region is considered a hotspot for $V$. parahaemolyticus infections with recurring cases of foodborne vibriosis and outbreaks since the late $1990 \mathrm{~s}^{[48]}$. Additionally, Rodriguez-Castro et al. ${ }^{[49]}$ reported the prevalence of pathogenic $V$. parahaemolyticus in coastal waters of Galicia, Spain. In Italy, pandemic V. parahaemolyticus 03:K6 strain was first isolated from a stool sample of a patient with diarrhea who was hospitalized in central Italy in the summer of $2007^{[50]}$. Lamon et al. ${ }^{[51]}$ reported the occurrence of potentially pathogenic $V$. parahaemolyticus from shellfish samples from two harvesting areas of Sardinia, Italy.

In the United States, V. parahaemolyticus was first identified as an etiological agent in 1971 after the three food-related epidemics of gastroenteritis in Maryland, which was associated with crab food product consumption ${ }^{[52]}$. Since then, recurrent $V$. parahaemolyticus outbreaks have been reported throughout the US coastal regions due to the consumption of raw or uncooked seafood. Between 1973 and 1998, the Centers for Disease Control and Prevention (CDC) have reported approximately 40 outbreaks of $V$. parahaemolyticus infection ${ }^{[53]}$. Among them, four major epidemics occurred in the Gulf Coast, Pacific Northwest, and Atlantic Northeast regions between 1997 and 1998, which involved $>700$ cases of illness that are associated with the consumption of raw oysters. In 1997, a massive outbreak was reported in North America, which included 209 people (including one death) of $V$. parahaemolyticus infections associated with consumption of raw oysters harvested from Oregon, Washington, and California in the US, and British Columbia (BC) in Canada ${ }^{[54]}$. Oyster-associated outbreaks of 43 cases in Washington and 416 cases in Texas in 1998 were caused by $V$. parahaemolyticus in the US ${ }^{[5]}$. In the summer of 2004, 22 passengers onboard a cruise ship developed gastroenteritis symptoms after ingesting raw oysters from the Alaskan waters ${ }^{[56]}$. In the summer of 2006, an outbreak of $V$. parahaemolyticus infection occurred, involving 
177 cases due to raw oyster ingestion that were harvested in Washington and $\mathrm{BC}^{[57]}$. DePaola et al. ${ }^{[58]}$ reported a prevalence of 04:K12, a serovariant of pandemic $V$. parahaemolyticus 03:K6 in the US. In the summer of 2010, another outbreak due to $V$. parahaemolyticus infection occurred in Maryland, which was linked to the consumption of oysters ${ }^{[59]}$. Furthermore, $V$. parahaemolyticus cases have increased in the Northeast USA, with outbreaks in New York in 2012 and New York, Connecticut, and Massachusetts in 2013 ${ }^{[60]}$. Almuhaideb et al. ${ }^{[61]}$ reported the prevalence of pathogenic $V$. parahaemolyticus in oyster (Crassostrea virginica) and water samples from Delaware Bay from June to October of 2016. Pathogenic V. parahaemolyticus is also reported from water, oyster, and sediment samples from the Chesapeake Bay, Maryland ${ }^{[62]}$.

In recent years, inland saline water has emerged as a potential farming aquaculture resource for rearing fish/shellfish species ${ }^{[34]}$. Some studies revealed the prevalence of $V$. parahaemolyticus in these sources ${ }^{[34,63,64]}$. Inland saline aquaculture refers to the culture of fish/shellfish or plants using inland sources of saline groundwater. Currently, inland saline aquaculture is practiced in many countries, including the USA, Israel, India, and Australia, to produce seafood ${ }^{[65]}$. Singh et al. ${ }^{[64]}$ reported the prevalence of $V$. parahaemolyticus in inland saline farms of Punjab. Sanathkumar et al. ${ }^{[63]}$ reported a high incidence of $V$. parahaemolyticus from shrimps in low saline (1-6 ppt) inland saline shrimp farms in the southeastern coast of India. Yano et al. ${ }^{[34]}$ reported the prevalence of $V$. parahaemolyticus (38\%) in shrimp samples from low saline (1-5 ppt) inland saline areas of Thailand.

\section{Virulence Factors}

The major virulence factors associated with $V$. parahaemolyticus are its toxins [thermostable direct hemolysin (TDH) and TDHrelated hemolysin (TRH)], type 3 secretion systems (T3SS1 and T3SS2), type 6 secretion systems, such as T6SS1 and T6SS2 ${ }^{[66-68]}$, and other virulence factors like adhesins, lipase, gelatinase activity, and urea hydrolysis ${ }^{[69]}$. Additionally, $V$. parahaemolyticus has two different types of flagellar systems, which help in swimming and swarming. These features are likely to assist in the strains' survival in the environment and the colonization of a human host ${ }^{[70]}$. Herein, we describe some of the virulence factors associated with $V$. parahaemolyticus, including studies on quorum sensing (OS), adhesins, toxins, type 3 secretion systems, type 6 secretion systems, and some other related factors to virulence, such as polar and lateral flagella, etc. (Figure 1).

\section{Quorum Sensing}

The expression of virulence factors in V. parahaemolyticus is modulated by the phenomenon known as QS. Bacterial QS is the regulation of gene expression in response to fluctuation in cell-population density. Quorum sensing bacteria produce and release signaling molecules (known as auto-inducers) that increases in concentration as a cell density function. It leads to gene expression alteration, which results in cell-tocell communication when a minimum threshold stimulatory concentration of an auto-inducer is detected ${ }^{[9]}$. These signaling molecules bind to receptor proteins on the bacterial surface and trigger a phosphorylation/dephosphorylation signal transduction cascade ${ }^{[71,72]}$. Bacteria use OS communication circuits to regulate a diverse array of physiological activities, such as virulence factor secretion, where bacterial cells function in harmony to coordinate alter their gene expression and control their synchrony-requiring activities ${ }^{[73]}$. At high cell densities, $V$. parahaemolyticus produces transcriptional regulator OpaR as a result of a response to $\mathrm{OS}$ system stimulation by auto-inducers, including auto-inducer $2(\mathrm{Al}-2)^{[71]}$. OpaR is the primary $\mathrm{OS}$ regulator that controls virulence factor gene expression, such as swarming motility, type 3 secretion, and type 6 secretion systems in V. parahaemolyticus ${ }^{[74]}$. Additionally, OpaR also controls the colony and cellular morphology that are associated with growth on a surface and biofilm formation ${ }^{[73]}$. Kernell Burke et al. ${ }^{[73]}$ suggested that the 11 transcription factors downstream of OpaR presumably play an essential role in the regulatory network that controls phenotypic output that is critical to the survival and

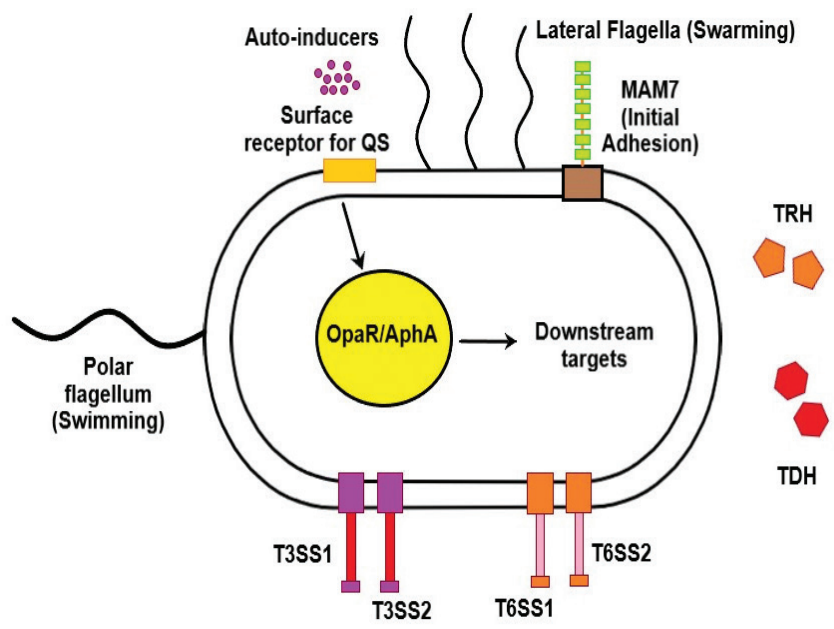

Figure 1. Virulence factors of Vibrio parahaemolyticus. The surface receptor for Quorum sensing (OS) reacts to stimulation and response by secreted auto-inducers (signaling molecule). OpaR/AphA are the transcriptional regulators that respond to auto-inducer stimulation and affect downstream targets. MAM7 is a multivalent adhesion protein that is responsible for its initial host cell attachment. A single polar flagellum is required for swimming motility in a moist environment, whereas lateral flagella aids in swarming motility and biofilm formation. T3SS (T3SS1 and T3SS2) to inject virulence proteins into the host cells. T6SS (T6SS1 and T6SS2) aids in adhesion to host cells. Toxins (TDH and $\mathrm{TRH}$ ) are the major virulence factors 
virulence of the organism. OpaR production is ceased and AphA is expressed at low cell densities, which is another transcriptional regulator and functions opposite to $\mathrm{OpaR}^{[71,75]}$. Expression of AphA represses the transcription of T3SS1 genes allowing $V$. parahaemolyticus to utilize this system for surviva[l]6]. The cytotoxicity caused by $V$. parahaemolyticus infection on tissue culture cells was significantly reduced with the deletion of AphA, supporting the role of OS in V. parahaemolyticus virulence ${ }^{[7]]}$.

\section{Adhesion to Host Cells}

The initial binding of bacteria to host cells is essential for the activation and delivery of virulence factors and thus is a vital determinant of the pathogen's success ${ }^{[78]}$. Multivalent adhesion molecule is an adhesin that is present in a wide range of Gram-negative pathogens, which enables them to establish a high-affinity binding to host cells during the early stages of infection ${ }^{[78]}$. Krachler et al. ${ }^{[78]}$ reported MAM7 as the outer membrane protein mediating host cell attachment in $V$. parahaemolyticus. MAM7 contains a transmembrane motif at the $\mathrm{N}$-terminus and seven mammalian cell entry (mce) domains that are also found in Mycobacterium spp. and some Grampositive bacteria species $^{[78]}$. MAM7 has two host receptors: extracellular matrix protein fibronectin and plasma membrane phospholipid phosphatidic acid (Table 1) ${ }^{[68]}$. MAM7 facilitates the attachment of bacteria to host cells by interacting with these two receptors, likely resulting in a tripartite complex on the bacterial and eukaryotic cell surface ${ }^{[78,79]}$. Furthermore, MAM7-mediated attachment augments T3SS-mediated cell death in some cell types. MAM7 discovery and characterization have led to new research insights as a novel therapeutic or prophylactic agent in combating not only $V$. parahaemolyticus but many other Gram-negative bacterial infections ${ }^{[78]}$.

\section{Toxins}

The TDH and TRH are the two virulence-associated factors with V. parahaemolyticus, which causes hemolysis and cytotoxicity in the host cell (Table 1) ${ }^{[70]}$. V. parahaemolyticus is extensively present in marine and estuarine environments, but not all strains are considered pathogenic ${ }^{[80]}$. Pathogenic strains are usually absent in environmental samples and lack the genes $t d h$ and trh, which cause diseases to humans and marine animals ${ }^{[22,81]}$. However, studies from Europe, Asia, and the US have reported approximately $0-6 \%$ of the environmental samples as positive for the presence of $V$. parahaemolyticus strains with $t d h$ and $t r h$ genes ${ }^{[55,82-84]}$. The isolated pathogenic strains from humans with gastroenteritis are differentiated from the environmental strains based on their ability to produce TDH. V. parahaemolyticus strains, which are TDH-positive, exhibits $\beta$-hemolytic properties on a special high-salt mannitol medium, Wagatsuma agar; this event is known as Kanagawa phenomenon (KP) ${ }^{[85,86]}$. The KP test is commonly used to identify pathogenic $V$. parahaemolyticus in seafood as well as patient samples. Kanagawa phenomenon test reproducibility is dependent on $\mathrm{pH}$, media salinity, and erythrocyte type. Thus, the identification of pathogenic serovars by this method is not always accurate. Only 1-2\% of samples from the environment are reported as KP-positive and the rest are considered KP-negative strains ${ }^{[86]}$. Molecular epidemiological studies indicate that $V$. parahaemolyticus KP-negative strains did not harbor the $t d h$ gene but had a trh gene. Qadri et al. ${ }^{[87]}$ reported the isolation of a KP-negative $V$. parahaemolyticus strain that carries the trh gene from a gastroenteritis outbreak in the Republic of Maldives in 1985. The trh gene is very similar to the $t d h$ as it plays a similar role in $V$. parahaemolyticus pathogenesis and is therefore regarded to be a $V$. parahaemolyticus virulence factor ${ }^{[88]}$.

TDH is a pore-forming toxin that consists of 165 amino acids ${ }^{[89,90]}$. During infection, a fairly large size of the pore causes the ion flux alteration in the intestine, which in turn causes diarrhea and other gastrointestinal disorders ${ }^{[9]}$. Studies explained its hemolytic, cytotoxic, enterotoxic, and cardiotoxic activities ${ }^{[00-92]}$. Approximately, 90\% of TDH pathogenicity is contributed by the $t d h 2$ gene compared to $t d h 1$, which produces nearly $10 \%$ of the total TDH ${ }^{[93]}$. This gene has been identified in some strains of $V$. mimicus, V. cholerae non-01/non-0139, and V. hollisa $e^{[94]}$.

TRH is a heat-labile toxin of $23 \mathrm{kDa}$ in size and can be destroyed by heat treatment at $60{ }^{\circ} \mathrm{C}$ for $10 \mathrm{~min}$. Takahashi et al. ${ }^{[95]}$ demonstrated the TRH-induced chloride secretion and intracellular calcium elevation in cultured human colonic epithelial cells. TRH-bearing strains are also capable of producing urease enzymes ${ }^{[33]}$. Studies revealed that trh gene bearing $V$. parahaemolyticus are more frequently distributed in tropical seafood than $t d h$ gene bearing $V$. parahaemolyticus ${ }^{[22,96,97]}$. The trh sequences consist of trh 1 and trh 2 genes and are approximately $70 \%$ identical to the $t d h$ sequence ${ }^{[98]}$.

Thermolabile hemolysin (TLH) is expressed by all clinical and environmental $V$. parahaemolyticus strains and can cause red blood cell lysis and shows lecithin-dependent phospholipase activity ${ }^{[99]}$. Studies revealed that TLH protein displays a sign of severe cytotoxicity on HeLa, Changliver, and RAW264.7 cells ${ }^{[100]}$. This suggests that TLH may have similar biological functions to TDH and TRH toxins, thereby playing a pivotal role in $V$. parahaemolyticus infection.

\section{Secretion Systems}

\section{Type 3 Secretion Systems}

Type 3 secretion systems, such as T3SS1 and T3SS2, and type 6 secretion systems, such as T6SS1 and T6SS2, have also been reported as virulence factors in $V$. parahaemolyticus like many other Gram-negative bacteria ${ }^{[66-68]}$. Type 3 secretion systems 
Table 1. List of known Vibrio parahaemolyticus virulence factors

\begin{tabular}{|c|c|c|c|c|c|}
\hline Effectors & Gene & Domain & Activity & Effects on host cells & References \\
\hline \multicolumn{6}{|c|}{ Toxins and adhesins } \\
\hline TDH & $t d h$ & $\begin{array}{l}\text { Thermostable direct } \\
\text { hemolysin }\end{array}$ & $\begin{array}{l}\text { Forms tetrameric pore } \\
\text { complexes in the host cell } \\
\text { membrane }\end{array}$ & $\begin{array}{l}\text { Causes cytotoxicity and } \\
\text { enterotoxicity }\end{array}$ & $\begin{array}{l}\text { Yanagihara et al. } .^{[105]} ; \\
\text { Matsuda et al. }{ }^{[00]} ; \text { Ohnishi } \\
\text { et al. }{ }^{[106]}\end{array}$ \\
\hline $\mathrm{TRH}$ & trh & TDH-related hemolysin & $\begin{array}{l}\text { Forms tetrameric pore } \\
\text { complexes in the host cell } \\
\text { membrane }\end{array}$ & $\begin{array}{l}\text { Causes cytotoxicity and } \\
\text { enterotoxicity }\end{array}$ & $\begin{array}{l}\text { Shinoda }{ }^{[94]} ; \text { Ohnishi et } \\
\text { al. }^{[106]} \text {; Shimohata and } \\
\text { Takahashi }^{[107]}\end{array}$ \\
\hline MAM7 & vp1611 & mce domain & $\begin{array}{l}\text { Binds to fibronectin and } \\
\text { phospholipid phosphatidic acid }\end{array}$ & $\begin{array}{l}\text { Initial attachment of the } \\
\text { bacterium to a host cell }\end{array}$ & $\begin{array}{l}\text { Krachler et al. } .^{[78]} ; \text { Krachler } \\
\text { and Orth }{ }^{[79]}\end{array}$ \\
\hline \multicolumn{6}{|c|}{ T3SS1 effectors } \\
\hline Vop0 & vp1680 & Non-conserved & $\begin{array}{l}\text { Forms pores and binds to } \\
\text { V-ATPase }\end{array}$ & Induces autophagy & $\begin{array}{l}\text { Burdette et al. }{ }^{[108]} ; \text { Ono et } \\
\text { al. }^{[109]} \text {; Matsuda et al. }{ }^{[110]}\end{array}$ \\
\hline VopR & vp1683 & Unknown & Binds PIP2 in membrane & $\begin{array}{l}\text { Promotes refolding of T3SS } \\
\text { effectors }\end{array}$ & Wang et al. ${ }^{[67]}$ \\
\hline VopS & vp1686 & Fic domain & AMPylates Rho-family GTPases & Disrupts actin cytoskeleton & $\begin{array}{l}\text { Yarbrough et al. }{ }^{[111]} ; \text { Luong } \\
\text { et al. }{ }^{[112]}\end{array}$ \\
\hline VPA0450 & vpa0450 & $\begin{array}{l}\text { Inositol polyphosphate } \\
\text { 5-phosphatase }\end{array}$ & Hydrolyzes $\mathrm{PI}(4,5) \mathrm{P}_{2}$ to $\mathrm{PI} 4 \mathrm{P}$ & $\begin{array}{l}\text { Disrupts plasma membrane } \\
\text { integrity }\end{array}$ & Broberg et al. ${ }^{[113]}$ \\
\hline \multicolumn{6}{|c|}{ T3SS2 effectors } \\
\hline VopC & vpa 1321 & $\begin{array}{l}\text { Cytotoxic necrotizing } \\
\text { factor-1 homolog }\end{array}$ & $\begin{array}{l}\text { Deamidates Rac and CDC42 at } \\
\text { their switch-2 region }\end{array}$ & $\begin{array}{l}\text { Disregulation of actin } \\
\text { network, Promotes invasion } \\
\text { to host cell }\end{array}$ & Zhang L et al..114] \\
\hline VopT & vpa1327 & ADP-ribosyltransferase & ADP-ribosylation of Ras & $\begin{array}{l}\text { Induces cytotoxicity, inhibits } \\
\text { growth of yeast }\end{array}$ & Kodama et al. ${ }^{[115]}$ \\
\hline VopA/P & vpa1346 & Acetyltransferase & $\begin{array}{l}\text { Inhibits MAPK signaling by } \\
\text { acetylation of MAPK kinases } \\
\text { (MKKs) }\end{array}$ & $\begin{array}{l}\text { Suppress immune response } \\
\text { and cytokine production }\end{array}$ & $\begin{array}{l}\text { Trosky et al. }{ }^{[116]} ; \text { Kodama } \\
\text { et al. }{ }^{[115]}\end{array}$ \\
\hline VopL & vpa1370 & $\begin{array}{l}\text { Wiskott-Aldrich } \\
\text { homology } 2(\mathrm{WH} 2) \text { and } \\
\text { proline rich region }\end{array}$ & $\begin{array}{l}\text { Nucleation of actin } \\
\text { polymerization }\end{array}$ & $\begin{array}{l}\text { Induces actin stress fiber } \\
\text { and filoform formations, } \\
\text { remodels host cell adherents } \\
\text { and tight junction, promotes } \\
\text { intestinal colonization, } \\
\text { inhibits host reactive oxygen } \\
\text { species (ROS) }\end{array}$ & $\begin{array}{l}\text { Liverman et al. }{ }^{[117]} ; \text { Miller } \\
\text { et al. }{ }^{[118]} ; \text { Zahm et al. }{ }^{[119]}\end{array}$ \\
\hline VopZ & vpa 1336 & Unknown & $\begin{array}{l}\text { Inhibits TAK1 activation, } \\
\text { Prevents NF-kB, and MAPK } \\
\text { signaling }\end{array}$ & $\begin{array}{l}\text { Enterotoxicity and promotes } \\
\text { colonization }\end{array}$ & $\begin{array}{l}\text { Zhou et al. }{ }^{[120]} ; \text { de Souza } \\
\text { Santos et al.. } .^{[121]}\end{array}$ \\
\hline VopV & vpa1357 & $\begin{array}{l}\text { F-actin binding } \\
\text { domains (LR and } \\
\text { C-Terminal domain) }\end{array}$ & Actin binding and bundling & $\begin{array}{l}\text { Causes cytotoxicity and } \\
\text { enterotoxicity, remodels } \\
\text { actin cytoskeleton and } \\
\text { intestinal brush border, } \\
\text { promotes colonization and } \\
\text { fluid accumulation }\end{array}$ & $\begin{array}{l}\text { Hiyoshi et al. }{ }^{[122]} ; \text { Zhou et } \\
\text { al. }^{[123]} \text {; Chaand et al. }{ }^{[124]}\end{array}$ \\
\hline VPA1380 & vpa1380 & Unknown & $\begin{array}{l}\text { Cysteine catalysis dependent } \\
\text { on inositol hexakisphosphate } \\
\text { (IP6) }\end{array}$ & Inhibits growth of yeast & Calder et al. ${ }^{[125]}$ \\
\hline
\end{tabular}

Adapted from Wang et al. ${ }^{[67]}$

(T3SS) or an injectisome is a nanomachine or needle-like bacterial machinery used to inject bacterial protein effectors across eukaryotic cell membranes without encountering the extracellular environment ${ }^{[101]}$. The primary role of type 3 secretion systems in V. parahaemolyticus is the host environment survival by releasing the crucial nutrients from the host cells through infected host cell lysis ${ }^{[102]}$. The T3SS1 is present in all environmental and clinical $V$. parahaemolyticus strains and is located on chromosome $1^{[102]}$. The T3SS2 is more commonly associated with pathogenic strains that carry the $t d h$ gene but 
not trh and is encoded on a pathogenicity island (Vp-PA1) on chromosome $2^{[102]}$. Another T3SS2 (T3SS2 $\beta$ ) of a different lineage has been identified in a $t d h$-negative, $t r h^{+} V$. parahaemolyticus strain $^{[103]}$. TSS1 is related to cytotoxic activity, whereas TTSS2 for enterotoxic activity ${ }^{[104]}$. T3SS1 initiates a series of events that involve autophagy, membrane blebbing, cell rounding, and lastly, cell lysis during tissue cell infection. The effectors associated with TISS1 are Vop0 (VP1680), VPA0450, VopR (VP1638), and VopS (VP1686) (Table 1). The effectors of T3SS2 include VopC (VPA1321), VopT (VPA1327), VopA/P (VPA1346), VopL (VPA1370), VopZ, VopV, and VPA1380 (Table 1) ${ }^{[67]}$.

\section{Type 6 Secretion Systems}

The type 6 secretion systems, T6SS1 (VP1386-VP1420) and T6SS2 (VPA1030-VPA1043) are located on chromosomes 1 and 2, respectively, on V. parahaemolyticus RIMD $2210633^{[126,127]}$. A study suggested that the T6SS systems in $V$. parahaemolyticus are functional for host cell adhesion and are not involved in cytotoxicity, as is the case with other bacterial T6SS ${ }^{[128]}$. T6SS1 and T3SS2 systems co-exist, thus both systems are suggested to cooperate during host infection. T6SS1 plays its role in adhesion, the first step of infection, and the T3SS2 export effectors that induce enterocytotoxicity ${ }^{[104,128]}$. T6SS gene is reported to be used as a virulence marker to distinguish pandemic and nonpandemic strains. Ceccarelli et al. ${ }^{[129]}$ reported the presence of T6SS gene in all pandemic strains during his study, whereas the non-pandemic strains had a partial set of T6SS genes. Additionally, researchers have reported that T6SS1 and T6SS2 require different temperature and salinity conditions to be active. T6SS1, which is predominantly found in clinical isolates, is most active under warm marine-like conditions, whereas T6SS2 is only active under low salt conditions and that surface sensing and OS differentially regulate both systems ${ }^{[130]}$.

\section{Other Virulence Factors}

\section{Flagella}

Apart from above- mentioned virulence factors, different types of flagella help in the strains' survival and colonization on a human host ${ }^{[70]}$. V. parahaemolyticus have two different types of flagellar systems, namely polar and lateral flagella, in which the polar flagellum is responsible for swimming and the lateral flagella for the swarmer cell type transformation and biofilm formation (Figure 1). V. parahaemolyticus is capable of swimming at speeds up to $60 \mu \mathrm{m} / \mathrm{s}$ with the aid of polar flagellum. The energy to rotate this flagellum is provided by a sodium motive force, which is advantageous in saltwater with an average $\mathrm{pH}$ of $8.0^{[131]}$. A decreased polar flagellum speed due to increased growth environment viscosity or growth under iron-limiting conditions induces the lateral flagella (swarmer cell type). These flagella are powered by proton motive force ${ }^{[131]}$.

\section{Others}

Other virulence factors include adhesiveness, lipase, gelatinase activity, and urea hydrolysis ${ }^{[69]}$. Ure gene is responsible for urease production in $V$. parahaemolyticus, and trh and ure gene are genetically linked ${ }^{[132]}$. Studies revealed that urease produced by $V$. parahaemolyticus causes intestinal fluid accumulation and shows a positive result in the suckling mouse test, thereby suggesting that the urease from $V$. parahaemolyticus may be an essential virulence factor in $t r h^{+} V$. parahaemolyticus strains ${ }^{[133,134]}$. The $U h$ gene encodes urease production, and the toxic effects of urease on intestinal mucosa permeability are thought to be due to ammonium ions accumulation during the infection process ${ }^{[135]}$.

\section{Pandemic Strains}

Gastroenteritis due to V. parahaemolyticus occurs as sporadic cases and is caused by $V$. parahaemolyticus of different serotypes. However, since 1996, incidences of gastroenteritis due to $V$. parahaemolyticus serotype 03:K6 have increased in many countries ${ }^{[47,136-138] \text {. }}$

This serotype was first recognized during the active surveillance of $V$. parahaemolyticus infection among hospitalized patients in Calcutta, India, between January 1994 and August 1996 ${ }^{[139]}$. The study identified a sudden increase in this serotype since 1996 and accounted for $50-80 \%$ of the $V$. parahaemolyticus strains isolated during the study period. This highly virulent strain was subsequently isolated from travelers who arrive in Japan from various Southeast Asian countries and was recovered at a high rate in other Southeast Asian countries ${ }^{[136,137,139]}$. V. parahaemolyticus 03:K6 serotype was first identified in the US in 1998 and caused the largest outbreak (416 people) due to the consumption of oysters from Galveston Bay ${ }^{[140]}$. The same serotype was later isolated from another outbreak of $V$. parahaemolyticus infection associated with eating raw oysters and clams among residents in Connecticut, New Jersey, and New York in July-September $1998^{[141]}$. In 2004, V. parahaemolyticus 03:K6 strain was isolated from victims of outbreaks that occurred in Chile ${ }^{[138]}$ and Spain ${ }^{[47]}$.

Currently, $>20$ serotypes of $V$. parahemolyticus are identified, including 03:K6, 04:K68, 01:K25, and 01:KUT ${ }^{[5]}$. Molecular analysis of the worldwide clinical isolates of $V$. parahaemolyticus demonstrated that a $24 \mathrm{~kb}$ region named $V$. parahaemolyticus island-1 (VPal-1) encompassing ORFs VP0380 to VP0403 is present only in new 03:K6 and related strains recovered after 1995. Further investigation showed the presence of 3 additional regions, VPal-4 (VP2131 to VP2144), VPal-5 (VP2900 to VP2910), and VPal-6 (VPA1254 to VPA1270) in the pandemic strains ${ }^{[142]}$. Nishioka et al. ${ }^{[143]}$ suggested VPAI1 as one of the pandemicity markers due to the presence of 
a virulence gene. In China, V. parahaemolyticus strains were isolated and screened for pandemic 03:K6 clone strains, the isolates in the pandemic group carried the $t d h$ but not the trh gene, and orf8 gene. Pandemic clonal serovars included 03:K6, 01:KUT, 01:K25, 01:K26, and 04:K68 and the newly emerging serovars $01: \mathrm{K} 36,03: \mathrm{K} 25$, and $03: \mathrm{K} 8^{[144]}$. Matsumoto et al. ${ }^{[31]}$ reported a novel toxRS-targeted polymerase chain reaction method that detected pandemic clones and suggested that the technique will be useful in differentiating between pandemic and non-pandemic $V$. parahaemolyticus strains. The differences among and between 03:K6 strains led to the definition of non-pandemic 03:K6 strains isolated in 1980-1990 in South Asian countries, including Taiwan, India, Thailand, Japan, and Bangladesh ${ }^{[129]}$.

In Chile, pandemic V. parahaemolyticus serotype 03:K6 strain caused one of the world's worst diarrhea outbreaks that are related to seafood consumption, with $>10,000$ clinical cases $^{[145]}$. In 2005, epidemics peaked in the Region de Los Lagos, Chile, where most seafood is produced. However, cases gradually decreased and disappeared a few years later ${ }^{[146]}$. In recent years, pandemic strains from environmental samples are growing, which constitute a new threat to seafood safety and human health. Meparambu Prabhakaran et al. ${ }^{[147]}$ isolated new serovars of pandemic $V$. parahaemolyticus strains from water, plankton, and seafood samples collected from the Indian coast. Caburlotto et al. ${ }^{[148]}$ reported pandemic strains of $V$. parahaemolyticus from environmental water samples in the Northern Adriatic, Italy. Recently, a new type of $V$. parahaemolyticus serotype named '04:KUT-recAin' was isolated from patients with acute diarrhea in coastal hospitals of China ${ }^{[149]}$. Hu et al. ${ }^{[150]}$ also reported the prevalence of 03:K6 V. parahaemolyticus serotype from aquatic products in the Southern Fujian coast, China.

\section{Antibiotic Resistance Proffles}

In addition to routine human and animal therapy applications, antibiotics were often used at sub-therapeutic levels in livestock, poultry production, and aquaculture to promote growth and prevent infection ${ }^{[151]}$. Antibiotic resistance has emerged and evolved in many bacterial genera, including Vibrio sp., over the past few decades due to excessive use of antibiotics in human, agricultural, and aquaculture systems ${ }^{[152,153]}$. Antibiotics from both urban and agricultural sources enter and persist in the aquatic environment, which results in resistant bacteria selection and survival. This selection pressure has promoted the evolution and spread of hundreds of antibiotic resistance genes that confer resistance to various bacteria, regardless of their origins ${ }^{[154]}$. Vibrio spp. are usually susceptible to most antibiotics of veterinary and human significance ${ }^{[155]}$. However, many studies reported that $V$. parahaemolyticus are gaining resistance to multiple antibiotics due to antibiotic misuse to control aquaculture infections (Table 2). Most frequently observed antibiotic resistance profiles involve ampicillin, penicillin, and tetracycline regardless of the countries ${ }^{[156]}$. The presence of multiple-antibiotic-resistant $V$. parahaemolyticus in aquatic environments and seafood is a major concern in fish and shellfish farming and human health. Most of these studies have been conducted in South Asian countries like India, China, Malaysia, Thailand, and South Korea (Table 2). Studies from other countries, like Brazil, Nigeria, Egypt, and Saudi Arabia, have also reported the prevalence of antibiotic resistance in $V$. parahaemolyticus from seafood and environmental samples in recent years (Table 2).

The increased bacterial resistance toward many clinical antibiotics affects many countries' healthcare and food production sectors. The CDC recommends antibiotics, such as fluoroquinolones (levofloxacin), cephalosporin (cefotaxime and ceftazidime), aminoglycosides (amikacin and gentamicin), and folate pathway inhibitors (trimethoprim-sulfamethoxazole) for Vibrio spp. Infection treatment ${ }^{[171]}$. However, various antibiotic resistance patterns among $V$. parahaemolyticus isolated from seafood and its environment in different countries have been observed (Table 2). A recent study on the antibiotic resistance of AHPND-causing $V$. parahaemolyticus strains isolated from shrimps (P. vannamei ${ }^{[172]}$ revealed that most isolates were resistant to colistin, ampicillin, and streptomycin but susceptible to other antibiotics. Another study revealed that $V$. parahaemolyticus isolates from oysters in coastal parts of West Bengal, India, exhibited resistance to cefpodoxime (100\%) followed by ampicillin and cefotaxime (90\%), ceftizoxime $(60 \%)$, tetracycline $(50 \%)$, ceftriaxone $(40 \%)$, ciprofloxacin, and nalidixic acid (10\% each) ${ }^{[173]}$. Mok et al. ${ }^{[174]}$ reported that V. parahaemolytics strains from water samples and aquatic animals (fish and shrimps) from aquaculture farms along the Korean coast exhibited resistance to two antibiotics (colistin and ampicillin). According to Ali et al. ${ }^{[175]}$, V. parahaemolyticus strains from marine fishes in Bangladesh were resistant to ampicillin (100\%) and streptomycin (78.9\%). The study of da Silva et al. ${ }^{[176]}$, revealed that $V$. parahaemolyticus from water and blue crab (Callinectes sapidus) samples from the Maryland Coastal Bays, United States, were resistant to cephalothin $(61 \%)$, cefoxitin $(31 \%)$, and ceftazidime $(29 \%)$. The reported high multiple antibiotic resistance of $V$. parahaemolyticus from seafood and its environment is of public health concern. Therefore, frequent investigation on the antimicrobial resistance of $V$. parahaemolyticus for epidemiological purposes and healthcare treatment guidance is necessary. 
Table 2. Antibiotic resistance profiles of Vibrio parahaemolyticus in some countries

\begin{tabular}{|c|c|c|c|c|c|c|}
\hline Country & Sampling site & Sample type & Resistant (\%) & Intermediate (\%) & Susceptible (\%) & References \\
\hline \multirow{4}{*}{ India } & $\begin{array}{l}\text { Shrimp farms } \\
\text { in Andhra } \\
\text { Pradesh and } \\
\text { Tamil Nadu }\end{array}$ & $\begin{array}{l}\text { Water and } \\
\text { shrimp }\end{array}$ & $\begin{array}{l}\text { Tetracycline (100); } \\
\text { amoxyclav (40); cefotaxime } \\
\text { (9); ticarcillin (5); ofloxacin } \\
\text { and ampicilin/sulbactam (3); } \\
\text { levofloxacin, minocycline, } \\
\text { chloramphenicol and } \\
\text { ciprofloxacin (2) }\end{array}$ & $\begin{array}{l}\text { Cephalothin (39); } \\
\text { cefotaxime (31); } \\
\text { amikacin (2) }\end{array}$ & $\begin{array}{l}\text { Nalidixic acid, meropenem, } \\
\text { norfloxacin and gentamicin } \\
\text { (100); levofloxacin, minocycline, } \\
\text { chloramphenicol, ciprofloxacin } \\
\text { and amikacin (98); ampicilin/ } \\
\text { sulbactam and ofloxacin (97) }\end{array}$ & $\begin{array}{l}\text { Navaneeth et } \\
\text { al. }^{[157]}\end{array}$ \\
\hline & $\begin{array}{l}\text { Retail markets } \\
\text { in Cochin, } \\
\text { Kerala }\end{array}$ & $\begin{array}{l}\text { Fish and } \\
\text { shellfish }\end{array}$ & $\begin{array}{l}\text { Ampicillin (79.3); } \\
\text { cefotaxime (41.4); cefepime } \\
\text { (10.3); cefoxitin and } \\
\text { ceftazidime (3.4) }\end{array}$ & $\begin{array}{l}\text { Cefepime (86.2); } \\
\text { cefoxitin (58.6); } \\
\text { ceftazidime (37.9); } \\
\text { cefotaxime (34.5); } \\
\text { ampicillin }(6.9) ; \\
\text { ciprofloxacin }(3.4)\end{array}$ & $\begin{array}{l}\text { Amoxicillin/clavulanic acid, } \\
\text { chloramphenicol, gentamicin, } \\
\text { meropenem, tetracycline and } \\
\text { trimethoprim/sulfamethoxazole } \\
\text { (100); ciprofloxacin (96.6); } \\
\text { ceftazidime (58.6); cefoxitin } \\
\text { (37.9); cefotaxime (24.1); } \\
\text { ampicillin (13.8) }\end{array}$ & $\begin{array}{l}\text { Narayanan et } \\
\text { al. }^{[39]}\end{array}$ \\
\hline & Cochin, Kerala & $\begin{array}{l}\text { Shellfish from } \\
\text { retail market }\end{array}$ & $\begin{array}{l}\text { Ampicillin, streptomycin } \\
\text { and cephalothin } \\
\text { (100); amoxycillin } \\
\text { (90); carbencillin (95); } \\
\text { ceftazidime (96); colistin } \\
\text { (95); gentamicin (10); } \\
\text { trimethoprim (10) }\end{array}$ & & $\begin{array}{l}\text { Chloramphenicol and } \\
\text { tetracycline (100) }\end{array}$ & $\begin{array}{l}\text { Sudha et } \\
\text { al. }^{[158]}\end{array}$ \\
\hline & $\begin{array}{l}\text { East coast of } \\
\text { India }\end{array}$ & $\begin{array}{l}\text { Water, } \\
\text { sediment } \\
\text { and shrimp } \\
\text { (Panaeus } \\
\text { monodon) }\end{array}$ & $\begin{array}{l}\text { Ampicillin (100); } \\
\text { furazolidone and neomycin } \\
\text { B (80); ceftriaxone } \\
\text { and ciprofloxacin } \\
\text { (60); chlortetracycline } \\
\text { chloramphenicol and } \\
\text { kanamycin (40); nalidixic } \\
\text { acid, oxytetracycline and } \\
\text { streptomycin (20) }\end{array}$ & $\begin{array}{l}\text { Oxytetracycline and } \\
\text { streptomycin (80); } \\
\text { chloramphenicol, } \\
\text { erythromycin and } \\
\text { nalidixic acid (60); } \\
\text { chlortetracycline, } \\
\text { ceftriaxone, } \\
\text { ciprofloxacin and } \\
\text { kanamycin (40); } \\
\text { furazolidone, } \\
\text { gentamicin and } \\
\text { neomycin B (20) }\end{array}$ & $\begin{array}{l}\text { Gentamicin (80); erythromycin } \\
\text { (40); chlortetracycline, } \\
\text { kanamycin and nalidixic acid } \\
(20)\end{array}$ & $\begin{array}{l}\text { Vaseeharan et } \\
\text { al. }^{[159]}\end{array}$ \\
\hline \multirow[t]{2}{*}{$\begin{array}{l}\text { South } \\
\text { Korea }\end{array}$} & $\begin{array}{l}\text { Restaurants in } \\
\text { Seoul }\end{array}$ & $\begin{array}{l}\text { Water } \\
\text { (restaurant } \\
\text { fish tank) }\end{array}$ & $\begin{array}{l}\text { Ampicillin (51.4); } \\
\text { amikacin and tetracycline } \\
\text { (11.4); ceftazidime } \\
\text { (8.6); cefotaxime and } \\
\text { ciprofloxacin (5.7); } \\
\text { ampicillin/sulbactam and } \\
\text { cefepime (2.9) }\end{array}$ & & $\begin{array}{l}\text { Piperacillin, imipenem, } \\
\text { gentamicin and trimethoprim/ } \\
\text { sulfamethoxazole (100); } \\
\text { ampicillin/sulbactam and } \\
\text { cefepime (97.1); cefotaxime and } \\
\text { ciprofloxacin (94.3); ceftazidime } \\
\text { (91.4); amikacin and tetracycline } \\
\text { (88.6); ampicillin (48.6) }\end{array}$ & Jeong et al. ${ }^{[160]}$ \\
\hline & $\begin{array}{l}\text { Fishery auction } \\
\text { markets, fish } \\
\text { markets, and } \\
\text { online markets }\end{array}$ & $\begin{array}{l}\text { Fishery } \\
\text { samples and } \\
\text { environmental } \\
\text { samples }\end{array}$ & Ampicillin (100) & & $\begin{array}{l}\text { Ciprofloxacin, amoxycillin/ } \\
\text { clavulanic acid, ampicillin- } \\
\text { sulbactam, chloramphenicol, } \\
\text { tetracyclines, and gentamicin } \\
(100)\end{array}$ & Lee et al..$^{[161]}$ \\
\hline \multirow[t]{2}{*}{ Italy } & $\begin{array}{l}\text { Italian coastal } \\
\text { waters } \\
\text { (Adriatic sea } \\
\text { and Tyrrhenian } \\
\text { sea) }\end{array}$ & $\begin{array}{l}\text { Shellfish } \\
\text { and clinical } \\
\text { samples } \\
\text { (feces) }\end{array}$ & $\begin{array}{l}\text { Ampicillin and amoxicillin } \\
(100) \text {; colistin sulfate, } \\
\text { polymyxin B, erythromycin, } \\
\text { kanamycin and neomycin } \\
(<20)\end{array}$ & $\begin{array}{l}\text { Tetracycline (11.2); } \\
\text { oxytetracycline (8.4) } \\
\text { and trimethoprim/ } \\
\text { sulfamethoxazole (3.7) }\end{array}$ & $\begin{array}{l}\text { Chloramphenicol and } \\
\text { doxycycline (100); oxolinic acid, } \\
\text { nalidixic acid, nitrofurantoin, } \\
\text { trimethoprim/sulfamethoxazole } \\
\text { and oxytetracycline }(>90) ; \\
\text { tetracycline and ciprofloxacin } \\
(>80)\end{array}$ & $\begin{array}{l}\text { Ottaviani et } \\
\text { al. }^{[162]}\end{array}$ \\
\hline & $\begin{array}{l}\text { Fish farm } \\
\text { (Adriatic sea) }\end{array}$ & $\begin{array}{l}\text { Water, } \\
\text { sediment, } \\
\text { and biofilm } \\
\text { samples }\end{array}$ & $\begin{array}{l}\text { Tetracycline (17); } \\
\text { trimethoprim- sulfadiazine } \\
\text { (7); trimethoprim (2) }\end{array}$ & & & $\begin{array}{l}\text { Labella et } \\
\text { al. }^{[163]}\end{array}$ \\
\hline Thailand & $\begin{array}{l}\text { Thap Put } \\
\text { district, Phang } \\
\text { Nga Province }\end{array}$ & $\begin{array}{l}\text { Oyster } \\
\text { (Crassostrea } \\
\text { lugubris and } \\
\text { C. belcheri) } \\
\text { and estuarine } \\
\text { water }\end{array}$ & $\begin{array}{l}\text { Erythromycin (54.2); } \\
\text { sulfamethoxazole } \\
\text { (34.7); trimethoprim } \\
\text { (27.9); ampicillin (10.2); } \\
\text { streptomycin (0.8); } \\
\text { tetracycline }(0.5)\end{array}$ & & $\begin{array}{l}\text { Chloramphenicol and } \\
\text { ciprofloxacin (100) }\end{array}$ & $\begin{array}{l}\text { Jeamsripong } \\
\text { et al. }{ }^{[164]}\end{array}$ \\
\hline
\end{tabular}


Table 2. Contiuned

\begin{tabular}{|c|c|c|c|c|c|c|}
\hline Country & Sampling site & Sample type & Resistant (\%) & Intermediate $(\%)$ & Susceptible $(\%)$ & References \\
\hline China & Hebei province & $\begin{array}{l}\text { Seafoods } \\
\text { (fish, mussel, } \\
\text { shrimp, crab, } \\
\text { sea-irchin, } \\
\text { scallop, clam, } \\
\text { and oyster) }\end{array}$ & $\begin{array}{l}\text { Ampicillin (100); } \\
\text { sulfisoxazole (47.36); } \\
\text { nitrofurantoin (34.21); } \\
\text { tobramycin ( } 31.57) ; \\
\text { sulfamethoxazole- } \\
\text { trimethoprim (26.31); } \\
\text { ceftriaxone (5.26); } \\
\text { gentamicin, cefoperazone } \\
\text { and cephalothin (2.63) }\end{array}$ & $\begin{array}{l}\text { Nitrofurantoin (42.1); } \\
\text { cefoperazone (39.47); } \\
\text { tobramycin (36.84); } \\
\text { gentamicin (31.57); } \\
\text { ciprofloxacin and } \\
\text { cephalothin (26.31); } \\
\text { ceftriazone (21.05); } \\
\text { ceftriaxone (15.78); } \\
\text { sulfamethoxazole- } \\
\text { trimethoprim and } \\
\text { ofloxacin (5.26); } \\
\text { norfloxacin (2.63) }\end{array}$ & $\begin{array}{l}\text { Chloramphenicol (100); } \\
\text { norfloxacin (97.36); ofloxacin } \\
\text { (94.73); ceftriaxone (78.94); } \\
\text { ciprofloxacin (73.68); } \\
\text { cephalothin (71.05); } \\
\text { trimethoprim (68.42); gentamicin } \\
\text { (65.78); cefoperazone (57.89); } \\
\text { sulfamethoxazole- Sulfisoxazole } \\
\text { (52.63); tobramycin (31.57); } \\
\text { nitrofurantoin (23.68) }\end{array}$ & Liu et al. ${ }^{[165]}$ \\
\hline Brazil & $\begin{array}{l}\text { Retail markets } \\
\text { in Natal (Rio } \\
\text { Grande do } \\
\text { Norte, Brazil) }\end{array}$ & $\begin{array}{l}\text { Shrimp } \\
\text { (Litopenaeus } \\
\text { vannamei) }\end{array}$ & $\begin{array}{l}\text { Ampicillin (90); amikacin } \\
(60)\end{array}$ & $\begin{array}{l}\text { Nitrofurantoin } \\
\text { (30); tetracycline } \\
\text { (40); amikacin (20); } \\
\text { ciprofloxacin (90); } \\
\text { sulfamethoxazole- } \\
\text { trimethoprim (10) }\end{array}$ & $\begin{array}{l}\text { Chloramphenicol (100); } \\
\text { nitrofurantoin (70); tetracycline } \\
\text { (60); amikacin (20); ciprofloxacin } \\
\text { (10); sulfamethoxazole- } \\
\text { trimethoprim (90) }\end{array}$ & $\begin{array}{l}\text { De Melo et } \\
\text { al. }{ }^{[166]}\end{array}$ \\
\hline
\end{tabular}

Cefotaxime (60); cefuroxime sodium (37.5); cephalothin Penicillin G (100); ampicillin (35.83); amikacin and cefazolin (84.17); Seafood cephalothin (54.17);

Malaysia Wet markets in sample (blood cefuroxime sodium (51.67) : clam, shrimp, amikacin (37.5); gentamicin surf clam, and (6.67); ceftazidime and squid) cefotaxime (5); ofloxacin (2.5); amoxicillin-clavulanic acid (0.83):
(33.33); gentamicin

(29.17); ofloxacin

(27.5); ceftazidime

(24.17); amoxicillinclavulanic acid

(23.33); cefazolin

(14.17); ampicillin

(10.83); tetracycline

(5.83); trimethoprim-

sulfamethoxazole (5)
Chloramphenicol (100); trimethoprim-sulfamethoxazole (95); tetracycline (94.17); amoxicillin-clavulanic acid (75.83); ceftazidime (70.83); ofloxacin (70); gentamicin

Tan et al.. ${ }^{[167]}$ (64.17); cefotaxime (35); amikacin (29.17); cefuroxime sodium (10.83); cephalothin (10): ampicillin (5); cefazolin (1.67)

\begin{tabular}{lll}
\hline Nigeria & $\begin{array}{l}\text { Open markets } \\
\text { in Edo and } \\
\text { Delta states }\end{array}$ & $\begin{array}{l}\text { Ready-to- } \\
\text { eat shrimp } \\
\text { samples }\end{array}$
\end{tabular}

Delta states
Amoxicillin (82.6); penicillin (86.9); doxycycline and trimethoprim (41.3); oxytetracycline (36.9); sulfamethoxazole (32.6); cefotaxime (30.4); tetracycline (28.3); amoxicillin/clavulanate and ampicillin/sulbactam (23.9)

Ampicillin, ampicillinsulbactam and tetracycline (100); ceftazidime Shrimp (97.2); cefotaxime (Penaeus Fish markets Egypt in Sharkia Governorate semisulcatus) and crabs (Portunus pelagicus) and ciprofloxacin (91.7); trimethoprimsulfamethoxazole (75); kanamycin (72.2); nalidixic acid (69.4); chloramphenicol (61.1); gentamicin (50); amikacin (30.6)

Carbenicillin (98); ampicillin (88); cephalothin (76); cefaclor (61); ticarcillin

Saudi

Coastline of

Arabia the Arabian Gulf
Seawater
(44); streptomycin (29); aztreonam (27); amikacin (12); cefoxitin and kanamycin (5); amoxy/ clavulanic (2)
Chloramphenicol (78.3); erythromycin (63); ciprofloxacin (52.2); streptomycin (50); doxycycline (39.1); cefotaxime (26.1); oxytetracycline (21.7)
Gentamycin and colistin (100)

Beshiru et al. $^{[168]}$
Chloramphenicol (22.2); kanamycin (11.1); cefotaxime and nalidixic acid (8.3); ciprofloxacin (2.8)
Amikacin (69.4); gentamicin (50); trimethoprim-sulfamethoxazole (25); nalidixic acid (22.2); Ahmed et kanamycin and chloramphenicol al. ${ }^{[169]}$ (16.7); ciprofloxacin (5.6); ceftazidime (2.8)
Kanamycin (71); streptomycin (66); (51); aztreonam (49); meropenem, nalidixic cefotaxime (41); amoxy/clavulanic (39); amikacin and ceftriaxone (29); ciprofloxacin (20); ampicillin and nitrofurantoin (12) acid, levofloxacin, and sulf./trimethoprim (100); tetracycline (98); cefepime (95); nitrofurantoin (85); ciprofloxacin and piperacillin (80); ceftizoxime (76); ceftriaxone (71)
Ghenem and Elhadi ${ }^{[170]}$ 


\section{Conclusion}

V. parahaemolyticus is a halophilic bacterium that naturally occurs in estuarine, marine, and coastal environments worldwide. It causes foodborne gastroenteritis, wound infection, and septicemia in humans and is an emerging threat to the shrimp aquaculture industry, which causes AHPND or EMS in shrimps. This review highlighted the prevalence of $V$. parahaemolyticus in various countries. The emergence of the pandemic clone and its ability to cause large outbreaks is of global concern. Routine monitoring and surveillance of seafood, environmental samples, and aquaculture areas, especially newly emerged inland saline areas, are of prime importance. Many virulence factors are associated with this pathogen, such as toxins, T3SS, T6SS, adhesins, urea hydrolysis, and flagellar motility, which alters the homeostasis and integrity of human cells. Most studies determine the virulence factors done in vitro with tissue culture cells, thus further studies are needed in vivo models. Additionally, the detailed mechanism of the combined effects of the virulence factors, which have evolved to work together, and the distinct functions of the individual effectors in causing pathogenicity are yet to be investigated. V. parahaemolyticus are usually susceptible to the majority of antibiotics of veterinary and human significance. However, many studies have reported multiple-antibiotic resistant $V$. parahaemolyticus from seafood and environmental samples in recent years. A high percentage of ampicillin and penicillin resistance suggests excluding these antibiotics as a treatment for infections due to this microorganism. Further research is needed to test the effectiveness of various antibiotics against $V$. parahaemolyticus. Effective control measures that combine novel drugs and other strategies such as probiotics and phage therapy to control infection in aquaculture are urgently required to avoid public health threats due to massive antibiotic misuse.

\section{Ethics}

Peer-review: Externally peer-reviewed.

\section{Authorship Contributions}

Concept: S.N., D.B., R.H., Design: S.M., S.K.S., R.H., S.V., C.N., M.S.D., Data Collection or Processing: S.N., S.M., D.B., S.V., D.W., A.S.S., Analysis or Interpretation: S.N., S.K.S., D.B., C.N., D.W., M.S.D., Literature Search: S.N., S.M., S.K.S., S.V., M.S.D., A.S.S., Writing: S.N., R.H., C.N., D.W., A.S.S.

Conflict of Interest: No conflict of interest was declared by the authors.

Financial Disclosure: The authors declared that this study received no financial support.

\section{References}

1. Xie T, Yu Q, Tang X, Zhao J, He X. Prevalence, antibiotic susceptibility and characterization of Vibrio parahaemolyticus isolates in China. FEMS Microbiol Lett. 2020;367:136.

2. Gode-Potratz CJ, Kustusch RJ, Breheny PJ, Weiss DS, McCarter LL. Surface sensing in Vibrio parahaemolyticus triggers a programme of gene expression that promotes colonization and virulence. Mol Microbiol. 2011;79:240-63.

3. DePaola A, Kaysner CA. Vibrio. Bacteriological analytical manual online, Washington DC: US Food and Drug Administration, 2004.

4. Parija SC. Textbook of Microbiology \&t Immunology-E-book. Elsevier Health Sciences, 2014.

5. Nair GB, Ramamurthy T, Bhattacharya SK, Dutta B, Takeda Y, Sack DA. Global dissemination of Vibrio parahaemolyticus serotype 03:K6 and its serovariants. Clin Microbiol Rev. 2007;20:39-48.

6. Chen X, Zhu Q, Liu Y, Wang R, Xie H, Chen J, Cheng Y, Zhang H, Cao L, Chen $\mathrm{Y}$. Pathogenic characteristics of and variation in Vibrio parahaemolyticus isolated from acute diarrhoeal patients in Southeastern China from 2013 to 2017. Infect Drug Resist. 2020;13:1307-18.

7. Zarei M, Borujeni MP, Jamnejad A, Khezrzadeh M. Seasonal prevalence of Vibrio species in retail shrimps with an emphasis on Vibrio parahaemolyticus. Food Control. 2012;25:107-9.

8. Pang R, Li Y, Chen M, Zeng H, Lei T, Zhang J, Ding Y, Wang J, Wu S, Ye Q, Zhang $\mathrm{J}, \mathrm{Wu} \mathrm{O}$. A database for risk assessment and comparative genomic analysis of foodborne Vibrio parahaemolyticus in China. Sci Data. 2020;7:321.

9. Zhang L, Orth K. Virulence determinants for Vibrio parahaemolyticus infection. Curr Opin Microbiol. 2013;16:70-7.

10. Li L, Meng H, Gu D, Li $Y$, Jia M. Molecular mechanisms of Vibrio parahaemolyticus pathogenesis. Microbiol Res. 2019;222:43-51.

11. Pui CF, Bilung LM, Zin NBM, Abidin NNBZ, Vincent M, Apun K. Risk of acquiring Vibrio parahaemolyticus in water and shrimp from an aquaculture farm. Kuroshio Sci. 2014;8:59-62.

12. Santos HM, Tsai CY, Maquiling KRA, Tayo LL, Mariatulqabtiah AR, Lee CW, Chuang KP. Diagnosis and potential treatments for acute hepatopancreatic necrosis disease (AHPND): a review. Aquac Int. 2020;28:169-85.

13. Peña-Navarro N, Castro-Vásquez R, Vargas-Leitón B, Dolz G. Molecular detection of acute hepatopancreatic necrosis disease (AHPND) in Penaeus vannamei shrimps in Costa Rica. Aquaculture. 2020;523:735190.

14. Tinwongger $S$, Proespraiwong $P$, Thawonsuwan J, Sriwanayos $P$ Kongkumnerd J, Chaweepack T, Mavichak R, Unajak S, Nozaki R, Kondo $H_{1}$ Hirono I. Development of PCR diagnosis for shrimp acute hepatopancreatic necrosis disease (AHPND) strain of Vibrio parahaemolyticus. Fish Dis Res. 2014;49:159-64.

15. Oliver JD, Pruzzo C, Vezzulli L, Kaper JB. Vibrio species. In: Michael PD, Robert LB (ed). Food Microbiology: Fundamentals and Frontiers. 4th ed. ASM Press, 2013:401-39.

16. Food and Drug Administration (FDA). Bacteriological analytical manual online. 8th ed. Arlington, Va: AOAC International, 2004.

17. Lesmana $M$, Subekti $D$, Simanjuntak $C H$, Tjaniadi $P$, Campbell JR, Oyofo BA. Vibrio parahaemolyticus associated with cholera-like diarrhoea among patients in North Jakarta, Indonesia. Diagn Microbiol Infect Dis. 2001;39:71-5

18. Cabrera-García ME, Vázquez-Salinas C, Quiñones-Ramírez El. Serologic and molecular characterization of Vibrio parahaemolyticus strains isolated from seawater and fish products of the Gulf of Mexico. Appl Environ Microbiol. 2004;70:6401-6.

19. Fujino T, Okuno Y, Nakada D, Aoyama A, Fukai K, Mukai T, Ueho T. On the bacteriological examination of shirasu-food poisoning. Med J Osaka Univ. 1953;4:299-304 
20. Aberoumand AU. Occurrence and pathogenic vibrios in the marine environment of potentially pathogenic the straits of Messina, Italy. World J Fish Mar Sci. 2010;3:76-382.

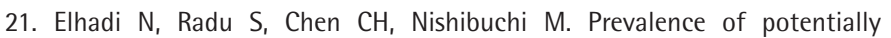
pathogenic Vibrio species in the seafood marketed in Malaysia. J Food Prot. 2004;67:1469-75.

22. Deepanjali A, Kumar HS, Karunasagar I, Karunasagar I. Seasonal variation in abundance of total and pathogenic Vibrio parahaemolyticus bacteria in oysters along the southwest coast of India. Appl Environ Microbiol. 2005;71:3575-80.

23. Hong To $\Pi$, Yanagawa $H$, Khanh Thuan $N$, Hiep DM, Cuong DV, Khai LTL, Taniguchi T, Kubo R, Hayashidani H. Prevalence of Vibrio parahaemolyticus causing acute hepatopancreatic necrosis disease of shrimp in shrimp, molluscan shellfish and water samples in the Mekong Delta, Vietnam. Biology (Basel). 2020;9:312.

24. Hara-Kudo $Y$, Saito $S$, Ohtsuka $K$, Yamasaki $S$, Yahiro S, Nishio T, Iwade $Y$, Otomo $Y$, Konuma H, Tanaka H, Nakagawa H, Sugiyama K, Sugita-Konishi $Y$, Kumagai S. Characteristics of a sharp decrease in Vibrio parahaemolyticus infections and seafood contamination in Japan. Int J Food Microbiol. 2012;157:95-101.

25. Kumagai $Y$, Pires SM, Kubota K, Asakura H. Attributing human foodborne diseases to food sources and water in Japan using analysis of outbreak surveillance data. J Food Prot. 2020;83:2087-94.

26. Yu WT, Jong KJ, Lin YR, Tsai SE, Tey YH, Wong HC. Prevalence of Vibrio parahaemolyticus in oyster and clam culturing environments in Taiwan. Int J Food Microbiol. 2013;160:185-92.

27. Lai YH, Chung YA, Wu YC, Fang CT, Chen PJ. Disease burden from foodborne illnesses in Taiwan, 2012-2015. J Formos Med Assoc. 2020;119:1372-81.

28. Liu X, Chen Y, Wang X, Ji R. Foodborne disease outbreaks in China from 1992 to 2001 national foodborne disease surveillance system. Wei Sheng Yan Jiu. 2004;33:725-7.

29. Li Y, Xie X, Shi X, Lin Y, Qiu Y, Mou J, Chen Q, Lu Y, Zhou L, Jiang M, Sun H, $\mathrm{Ma} \mathrm{H}_{1}$ Cheng J, Hu Q. Vibrio parahaemolyticus, southern coastal region of China, 2007-2012. Emerg Infect Dis. 2014;20:685-8.

30. Li Y, Xie T, Pang R, Wu O, Zhang J, Lei T, Xue L, Wu H, Wang J, Ding Y, Chen M, Wu S, Zeng H, Zhang Y, Wei X. Food-borne Vibrio parahaemolyticus in China: Prevalence, antibiotic susceptibility, and genetic characterization. Front Microbiol. 2020;11:1670.

31. Matsumoto $C$, Okuda J, Ishibashi $M$, Iwanaga $M$, Garg $P$, Rammamurthy $T$, Wong HC, Depaola A, Kim YB, Albert MJ, Nishibuchi M. Pandemic spread of an 03:K6 clone of Vibrio parahaemolyticus and emergence of related strains evidenced by arbitrarily primed PCR and toxRS sequence analyses. J Clin Microbiol. 2000;38:578-85.

32. Bhuiyan NA, Ansaruzzaman M, Kamruzzaman M, Alam $K$, Chowdhury NR, Nishibuchi M, Faruque SM, Sack DA, Takeda Y, Nair GB. Prevalence of the pandemic genotype of Vibrio parahaemolyticus in Dhaka, Bangladesh, and significance of its distribution across different serotypes. J Clin Microbiol. 2002;40:284-6.

33. Nakaguchi Y. Contamination with Vibrio parahaemolyticus and its virulent strains in seafood marketed in Thailand, Vietnam, Malaysia, and Indonesia. Trop Med Health. 2013;41:95-102.

34. Yano Y, Hamano K, Satomi M, Tsutsui I, Ban M, Aue-Umneoy D. Prevalence and antimicrobial susceptibility of Vibrio species related to food safety isolated from shrimp cultured at inland ponds in Thailand. Food Control. 2014;38:30-6.

35. Al-Othrubi SM, Kqueen CY, Mirhosseini H, Hadi YA, Radu S. Antibiotic resistance of Vibrio parahaemolyticus isolated from cockles and shrimp sea food marketed in Selangor, Malaysia. Clin Microbiol. 2014;3:148-54.

36. Chatterjee BD, Neogy KN, Gorbach SL. Study of Vibrio parahaemolyticus from cases of diarrhoea in Calcutta. Indian J Med Res. 1970;58:234-8.
37. Pazhani GP, Bhowmik SK, Ghosh S, Guin S, Dutta S, Rajendran K, Saha DR, Nandy RK, Bhattacharya MK, Mukhopadhyay AK, Ramamurthy T. Trends in the epidemiology of pandemic and non-pandemic strains of Vibrio parahaemolyticus isolated from diarrheal patients in Kolkata, India. PLoS Negl Trop Dis. 2014;8:e2815.

38. Reyhanath PV, Kutty R. Incidence of multidrug resistant Vibrio parahaemolyticus isolated from Ponnani, South India. Iran J Microbiol. 2014;6:60-7.

39. Narayanan SV, Joseph TC, Peeralil S, Mothadaka MP, Lalitha KV. Prevalence, Virulence characterization, AMR pattern and genetic relatedness of Vibrio parahaemolyticus isolates from retail seafood of Kerala, India. Front Microbiol. 2020;11:592.

40. Guin S, Saravanan M, Anjay, Chowdhury G, Pazhani GP, Ramamurthy T, Chandra Das S. Pathogenic Vibrio parahaemolyticus in diarrhoeal patients, fish and aquatic environments and their potential for inter-source transmission. Heliyon. 2019;5:e01743.

41. Miwatani T, Takeda Y. Vibrio parahaemolyticus: A Causative Bacterium of Food Poisoning. Tokyo: Saikon Publication, 1976.

42. Aldova E, Zakhariev ZA, Dinev TS, Zlatanov ZT. Vibrio parahaemolyticus in the Black Sea. Zentralbl Bakteriol Orig A. 1971;218:176-88.

43. Papa F. Study and significance of Vibrio parahaemolyticus in the coastal waters of Guadeloupe. Bull Soc Pathol Exot Filiales. 1980;73:380-3.

44. Lozano-León A, Torres J, Osorio CR, Martínez-Urtaza J. Identification of tdh-positive Vibrio parahaemolyticus from an outbreak associated with raw oyster consumption in Spain. FEMS Microbiol Lett. 2003;226:281-4.

45. Robert-Pillot A, Guénolé A, Lesne J, Delesmont R, Fournier JM, Quilici ML. Occurrence of the tdh and trh genes in Vibrio parahaemolyticus isolates from waters and raw shellfish collected in two French coastal areas and from seafood imported into France. Int J Food Microbiol. 2004;91:319-25.

46. Briet A, Helsens N, Delannoy S, Debuiche S, Brisabois A, Midelet G, Granier SA. NDM-1-producing Vibrio parahaemolyticus isolated from imported seafood. J Antimicrob Chemother. 2018;73:2578-9.

47. Martinez-Urtaza J, Simental L, Velasco D, DePaola A, Ishibashi M, Nakaguchi Y, Nishibuchi M, Carrera-Flores D, Rey-Alvarez C, Pousa A. Pandemic Vibrio parahaemolyticus 03:K6, Europe. Emerg Infect Dis. 2005;11:1319-20.

48. Martinez-Urtaza J, Trinanes J, Abanto M, Lozano-Leon A, Llovo-Taboada J, Garcia-Campello M, Pousa A, Powell A, Baker-Austin C, Gonzalez-Escalona N. Epidemic dynamics of Vibrio parahaemolyticus illness in a hotspot of disease emergence, Galicia, Spain. Emerg Infect Dis. 2018;24:852-9.

49. Rodriguez-Castro A, Ansede-Bermejo J, Blanco-Abad V, Varela-Pet J, Garcia-Martin 0, Martinez-Urtaza J. Prevalence and genetic diversity of pathogenic populations of Vibrio parahaemolyticus in coastal waters of Galicia, Spain. Environ Microbiol Rep. 2010;2:58-66.

50. Ottaviani D, Leoni F, Rocchegiani E, Santarelli S, Canonico C, Masini L, Ditrani V, Carraturo A. First clinical report of pandemic Vibrio parahaemolyticus 03:K6 infection in Italy. J Clin Microbiol. 2008;46:2144-5.

51. Lamon S, Consolati SG, Fois F, Cambula MG, Pes M, Porcheddu G, Agus V, Esposito G, Mureddu A, Meloni D. Occurrence, seasonal distribution, and molecular characterization of Vibrio vulnificus, Vibrio cholerae, and Vibrio parahaemolyticus in shellfish (Mytilus galloprovincialis and Ruditapes decussatus) collected in Sardinia (Italy). J Food Prot. 2019;82:1851-6.

52. Molenda JR, Johnson WG, Fishbein M, Wentz B, MehIman IJ, Dadisman TA Jr. Vibrio parahaemolyticus gastroenteritis in Maryland: laboratory aspects. Appl Microbiol. 1972;24:444-8.

53. Daniels NA, MacKinnon L, Bishop R, Altekruse $S$, Ray B, Hammond RM, Thompson S, Wilson S, Bean NH, Griffin PM, Slutsker L. Vibrio parahaemolyticus infections in the United States, 1973-1998. J Infect Dis. 2000;181:1661-6.

54. Centers for Disease Control and Prevention (CDC). Outbreak of Vibrio parahaemolyticus infections associated with eating raw oysters--Pacific Northwest, 1997. MMWR Morb Mortal Wkly Rep. 1998;47:457-62. 
55. DePaola A, Kaysner CA, Bowers J, Cook DW. Environmental investigations of Vibrio parahaemolyticus in oysters after outbreaks in Washington, Texas, and New York (1997 and 1998). Appl Environ Microbiol. 2000;66:4649-54.

56. McLaughlin JB, DePaola A, Bopp CA, Martinek KA, Napolilli NP, Allison CG, Murray SL, Thompson EC, Bird MM, Middaugh JP. Outbreak of Vibrio parahaemolyticus gastroenteritis associated with Alaskan oysters. N Engl J Med. 2005;353:1463-70.

57. Centers for Disease Control and Prevention (CDC). Vibrio parahaemolyticus infections associated with consumption of raw shellfish-three states, 2006. MMWR Morb Mortal Wkly Rep. 2006;55:854-6.

58. DePaola A, Ulaszek J, Kaysner CA, Tenge BJ, Nordstrom JL, Wells J, Puhr N, Gendel SM. Molecular, serological, and virulence characteristics of Vibrio parahaemolyticus isolated from environmental, food, and clinical sources in North America and Asia. Appl Environ Microbiol. 2003;69:3999-4005.

59. Haendiges J, Jones J, Myers RA, Mitchell CS, Butler E, Toro M, GonzalezEscalona N. A nonautochthonous US strain of Vibrio parahaemolyticus isolated from Chesapeake Bay oysters caused the outbreak in Maryland in 2010. Appl Environ Microbiol. 2016;82:3208-16.

60. Newton AE, Garrett N, Stroika SG, Halpin JL, Turnsek M, Mody RK; Centers for Disease Control and Prevention (CDC). Increase in Vibrio parahaemolyticus infections associated with consumption of Atlantic Coast shellfish--2013. MMWR Morb Mortal Wkly Rep. 2014;63:335-6.

61. Almuhaideb E, Chintapenta LK, Abbott A, Parveen S, Ozbay G. Assessment of Vibrio parahaemolyticus levels in oysters (Crassostrea virginica) and seawater in Delaware Bay in relation to environmental conditions and the prevalence of molecular markers to identify pathogenic Vibrio parahaemolyticus strains. Plos One. 2020;15:e0242229.

62. Chen AJ, Hasan NA, Haley BJ, Taviani E, Tarnowski M, Brohawn K, Johnson CN, Colwell RR, Huq A. Characterization of pathogenic Vibrio parahaemolyticus from the Chesapeake Bay, Maryland. Front Microbiol. 2017;8:2460.

63. Sanathkumar H, Ravi C, Padinhatupurayil SB, Mol M, Prasad JK, Nayak BB. Microbiological investigation of persistent mortalities in Litopenaeus vannamei grown in low saline waters in India. J Aquat Anim Health. 2014;26:154-9.

64. Singh B, Tyagi A, Billekallu Thammegowda NK, Ansal MD. Prevalence and antimicrobial resistance of Vibrios of human health significance in inland saline aquaculture areas. Aquac Res. 2018;49:2166-74.

65. Allan GL, Fielder DS, Fitzsimmons KM, Applebaum SL, Raizada S. Inland saline aquaculture. New Technologies in Aquaculture. Woodhead Publishing, 2009:1119-47.

66. Makino K, Oshima K, Kurokawa K, Yokoyama K, Uda T, Tagomori K, lijima $Y$, Najima $M$, Nakano $M$, Yamashita $A$, Kubota $Y$, Kimura $S$, Yasunaga T, Honda T, Shinagawa $H$, Hattori M, lida T. Genome sequence of Vibrio parahaemolyticus: a pathogenic mechanism distinct from that of $\mathrm{V}$. cholerae. Lancet. 2003;361:743-9.

67. Wang $R$, Zhong $Y$, Gu X, Yuan J, Saeed AF, Wang S. The pathogenesis, detection, and prevention of Vibrio parahaemolyticus. Front Microbiol. 2015;6:144.

68. Ghenem L, Elhadi N, Alzahrani F, Nishibuchi M. Vibrio parahaemolyticus: A review on distribution, pathogenesis, virulence determinants and epidemiology. Saudi J Med Med Sci. 2017;5:93-103.

69. Drake SL, DePaola A, Jaykus LA. An overview of Vibrio vulnificus and Vibrio parahaemolyticus. Compr Rev Food Sci Food Saf. 2007;6:120-44.

70. Broberg CA, Calder TJ, Orth K. Vibrio parahaemolyticus cell biology and pathogenicity determinants. Microb Infect. 2011;13:992-1001.

71. Zhang Y, Qiu Y, Tan Y, Guo Z, Yang R, Zhou D. Transcriptional regulation of opaR, qrr2-4 and aphA by the master quorum-sensing regulator OpaR in Vibrio parahaemolyticus. PLoS One. 2012;7:e34622.

72. Trimble MJ, McCarter LL. Bis- $\left(3^{\prime}-5^{\prime}\right)$-cyclic dimeric GMP-linked quorum sensing controls swarming in Vibrio parahaemolyticus. Proc Natl Acad Sci. 2011;108:18079-84.
73. Kernell Burke A, Guthrie LT, Modise T, Cormier G, Jensen RV, McCarter LL, Stevens AM. OpaR controls a network of downstream transcription factors in Vibrio parahaemolyticus BB22OP. PloS one. 2015;10:e0121863.

74. Gode-Potratz CJ, McCarter LL. Quorum sensing and silencing in Vibrio parahaemolyticus. J Bacteriol. 2011;193:4224-37.

75. S Sun F, Zhang Y, Wang L, Yan X, Tan Y, Guo Z, Qiu J, Yang R, Xia P, Zhou D. Molecular characterization of direct target genes and cis-acting consensus recognized by quorum-sensing regulator AphA in Vibrio parahaemolyticus. PLoS One. 2012;7:e44210.

76. Burdette DL, Yarbrough ML, Orvedahl A, Gilpin CJ, Orth K. Vibrio parahaemolyticus orchestrates a multifaceted host cell infection by induction of autophagy, cell rounding, and then cell lysis. Proc Natl Acad Sci U S A. 2008;105:12497-502.

77. Wang $L$, Ling $Y$, Jiang $H$, Qiu $Y$, Qiu J, Chen $H$, Yang R, Zhou D. AphA is required for biofilm formation, motility, and virulence in pandemic Vibrio parahaemolyticus. Int J Food Microbiol. 2013;160:245-51.

78. Krachler AM, Ham H, Orth K. Outer membrane adhesion factor multivalent adhesion molecule 7 initiates host cell binding during infection by Gramnegative pathogens. Proc Natl Acad Sci U S A. 2011;108:11614-9.

79. Krachler AM, Orth K. Functional characterization of the interaction between bacterial adhesin multivalent adhesion molecule 7 (MAM7) protein and its host cell ligands. J Biol Chem. 2011;286:38939-47.

80. Velazquez-Roman J, León-Sicairos N, Flores-Villaseñor H, Villafaña-Rauda $\mathrm{S}$, Canizalez-Roman A. Association of pandemic Vibrio parahaemolyticus 03:K6 present in the coastal environment of Northwest Mexico with cases of recurrent diarrhea between 2004 and 2010. Appl Environ Microbiol. 2012;78:1794-803.

81. West $\mathrm{CKG}$, Klein $\mathrm{SL}$, Lovell CR. High frequency of virulence factor genes $\mathrm{tdh}$, trh, and th in Vibrio parahaemolyticus strains isolated from a pristine estuary. Appl Environ Microbiol. 2013;79:2247-52.

82. Wong HC, Liu SH, Wang TK, Lee CL, Chiou CS, Liu DP, Nishibuchi M, Lee BK. Characteristics of Vibrio parahaemolyticus 03:K6 from Asia. Appl Environ Microbiol. 2000;66:3981-6.

83. Hervio-Heath $D$, Colwell RR, Derrien A, Robert-Pillot $A$, Fournier JM, Pommepuy M. Occurrence of pathogenic Vibrios in coastal areas of France. J Appl Microbiol. 2002;92:1123-35.

84. Alam MJ, Tomochika KI, Miyoshi SI, Shinoda S. Environmental investigation of potentially pathogenic Vibrio parahaemolyticus in the Seto-Inland Sea, Japan. FEMS Microbiol Lett. 2002;208:83-7.

85. Nishibuchi M, Taniguchi T, Misawa T, Khaeomanee-lam V, Honda T, Miwatani T. Cloning and nucleotide sequence of the gene (trh) encoding the hemolysin related to the thermostable direct hemolysin of Vibrio parahaemolyticus. Infect Immun. 1989;57:2691-7.

86. Alipour M, Issazadeh K, Soleimani J. Isolation and identification of Vibrio parahaemolyticus from seawater and sediment samples in the southern coast of the Caspian Sea. Comp Clin Path. 2014;23:129-33.

87. Qadri F, Chowdhury NR, Takeda Y, Nair GB. Vibrio parahaemolyticus-seafood safety and associations with higher organisms. In: Belkin S, Colwell RR (ed). Oceans and health: Pathogens in the Marine Environment. Boston, MA: Springer, 2005:277-95.

88. Nelapati S, Nelapati K, Chinnam BK. Vibrio parahaemolyticus-An emerging foodborne pathogen-A Review. Vet World. 2012;5:48-62.

89. Hamada $D$, Higurashi $T$, Mayanagi $K$, Miyata $T$, Fukui $T$, lida $T$, Honda $T$, Yanagihara I. Tetrameric structure of thermostable direct hemolysin from Vibrio parahaemolyticus revealed by ultracentrifugation, small-angle X-ray scattering and electron microscopy. J Mol Biol. 2007;365:187-95.

90. Matsuda S, Kodama T, Okada N, Okayama K, Honda T, lida T. Association of Vibrio parahaemolyticus thermostable direct hemolysin with lipid rafts is essential for cytotoxicity but not hemolytic activity. Infect Immun. 2010;78:603-10. 
91. Raghunath P. Roles of thermostable direct hemolysin (TDH) and TDH-related hemolysin (TRH) in Vibrio parahaemolyticus. Front Microbiol. 2015;5:805.

92. Honda $\mathrm{T}, \mathrm{Ni}$ Y, Miwatani T, Adachi T, Kim J. The thermostable direct hemolysin of Vibrio parahaemolyticus is a pore-forming toxin. Can J Microbiol. 1992;38:1175-80.

93. Pal D, Das N. Isolation, identification and molecular characterization of Vibrio parahaemolyticus from fish samples in Kolkata. Eur Rev Med Pharmacol Sci. 2010;14:545-9.

94. Shinoda S. Sixty years from the discovery of Vibrio parahaemolyticus and some recollections. Biocontrol Sci. 2011;16:129-37.

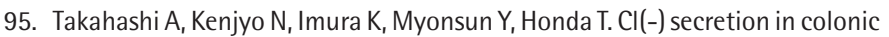
epithelial cells induced by the Vibrio parahaemolyticus hemolytic toxin related to thermostable direct hemolysin. Infect Immun. 2000;68:5435-8.

96. Parvathi A, Kumar HS, Bhanumathi A, Ishibashi M, Nishibuchi M, Karunasagar I, Karunasagar I. Molecular characterization of thermostable direct haemolysin-related haemolysin (TRH)-positive Vibrio parahaemolyticus from oysters in Mangalore, India. Environ Microbiol. 2006;8:997-1004.

97. Raghunath P, Karunasagar I, Karunasagar I. Improved isolation and detection of pathogenic Vibrio parahaemolyticus from seafood using a new enrichment broth. Int J Food Microbiol. 2009;129:200-3.

98. Kishishita M, Matsuoka N, Kumagai K, Yamasaki S, Takeda Y, Nishibuchi $M$. Sequence variation in the thermostable direct hemolysin-related hemolysin (trh) gene of Vibrio parahaemolyticus. Appl Environ Microbiol. 1992;58:2449-57.

99. Elola-Lopez A, Esquivel MJ, Bergmann C, Beltran S, Osorio G, Trombert AN. PCR restriction fragment length polymorphism analyses of $V$. parahaemolyticus MAM-7 virulence gene in clinical and environmental strains. Electron J Biol. 2015;11:119-25.

100. Wang R, Fang S, Wu D, Lian J, Fan J, Zhang Y, Wang S, Lin W. Screening for a single-chain variable-fragment antibody that can effectively neutralize the cytotoxicity of the Vibrio parahaemolyticus thermolabile hemolysin. Appl Environ Microbiol. 2012;78:4967-75.

101. Cornelis GR. The type III secretion injectisome. Nat Rev Microbiol. 2006;4:811-25.

102. Paranjpye R, Hamel OS, Stojanovski A, Liermann M. Genetic diversity of clinical and environmental Vibrio parahaemolyticus strains from the Pacific Northwest. Appl Environ Microbiol. 2012;78:8631-8.

103. Okada N, lida T, Park KS, Goto N, Yasunaga T, Hiyoshi H, Matsuda S, Kodama $\mathrm{T}$, Honda T. Identification and characterization of a novel type III secretion system in trh-positive Vibrio parahaemolyticus strain TH3996 reveal genetic lineage and diversity of pathogenic machinery beyond the species level. Infect Immun. 2009;77:904-13.

104. Park KS, Ono $T$, Rokuda $M$, Jang $M H$, Okada $K$, lida $T$, Honda $T$. Functional characterization of two type III secretion systems of Vibrio parahaemolyticus. Infect Immun. 2004;72:6659-65.

105. Yanagihara I, Nakahira K, Yamane T, Kaieda S, Mayanagi K, Hamada D, Fukui T, Ohnishi K, Kajiyama S, Shimizu T, Sato M, Ikegami T, Ikeguchi $M$, Honda $T$, Hashimoto $H$. Structure and functional characterization of Vibrio parahaemolyticus thermostable direct hemolysin. J Biol Chem. 2010;285:16267-74.

106. Ohnishi K, Nakahira K, Unzai S, Mayanagi K, Hashimoto H, Shiraki K, Honda T, Yanagihara I. Relationship between heat-induced fibrillogenicity and hemolytic activity of thermostable direct hemolysin and a related hemolysin of Vibrio parahaemolyticus. FEMS Microbiol Lett. 2011;318:107.

107. Shimohata $T$, Takahashi A. Diarrhea induced by infection of Vibrio parahaemolyticus. J Med Investig. 2010;57:179-82.

108. Burdette DL, Seemann J, Orth K. Vibrio Vop0 induces PI3-kinaseindependent autophagy and antagonizes phagocytosis. Mol Microbiol. 2009;73:639-49.
109. Ono T, Park KS, Ueta M, lida $T$, Honda T. Identification of proteins secreted via Vibrio parahaemolyticus type III secretion system 1. Infect Immun. 2006;74:1032-42.

110. Matsuda S, Okada N, Kodama T, Honda T, lida T. A cytotoxic type III secretion effector of Vibrio parahaemolyticus targets vacuolar H+-ATPase subunit c and ruptures host cell lysosomes. PLoS Pathog. 2012;8:e1002803.

111. Yarbrough ML, Li Y, Kinch LN, Grishin NV, Ball HL, Orth K. AMPylation of Rho GTPases by Vibrio VopS disrupts effector binding and downstream signaling. Science. 2009;323:269-72.

112. Luong P, Kinch LN, Brautigam CA, Grishin NV, Tomchick DR, Orth K. Kinetic and structural insights into the mechanism of AMPylation by VopS Fic domain. J Biol Chem. 2010;285:20155-63.

113. Broberg CA, Zhang L, Gonzalez H, Laskowski-Arce MA, Orth K. A Vibrio effector protein is an inositol phosphatase and disrupts host cell membrane integrity. Science. 2010;329:1660-2.

114. Zhang L, Krachler AM, Broberg CA, Li Y, Mirzaei H, Gilpin CJ, Orth K. Type III effector VopC mediates invasion for Vibrio species. Cell Rep. 2012;1:45360.

115. Kodama T, Rokuda M, Park KS, Cantarelli W, Matsuda S, lida T, Honda T. Identification and characterization of VopT, a novel ADP-ribosyltransferase effector protein secreted via the Vibrio parahaemolyticus type III secretion system 2. Cell Microbiol. 2007;9:2598-609.

116. Trosky JE, Mukherjee S, Burdette DL, Roberts M, McCarter L, Siegel RM, Orth K. Inhibition of MAPK signaling pathways by VopA from Vibrio parahaemolyticus. J Biol Chem. 2004;279:51953-7.

117. Liverman AD, Cheng HC, Trosky JE, Leung DW, Yarbrough ML, Burdette DL, Rosen MK, Orth K. Arp2/3-independent assembly of actin by Vibrio type III effector VopL. Proc Natl Acad Sci U S A. 2007;104:17117-22.

118. Miller KA, Sofia MK, Weaver JWA, Seward CH, Dziejman M. Regulation by ToxR-like proteins converges on vttRB expression to control type 3 secretion system-dependent Caco2-BBE cytotoxicity in Vibrio cholerae. J Bacteriol. 2016;198:1675-82.

119. Zahm JA, Padrick SB, Chen Z, Pak CW, Yunus AA, Henry L, Tomchick $D R$, Chen $Z$, Rosen MK. The bacterial effector VopL organizes actin into filament-like structures. Cell. 2013;155:423-34.

120. Zhou X, Gewurz BE, Ritchie JM, Takasaki K, Greenfeld H, Kieff E, Davis BM, Waldor MK. A Vibrio parahaemolyticus T3SS effector mediates pathogenesis by independently enabling intestinal colonization and inhibiting TAK1 activation. Cell Rep. 2013;3:1690-702.

121. de Souza Santos M, Salomon D, Orth K. T3SS effector VopL inhibits the host ROS response, promoting the intracellular survival of Vibrio parahaemolyticus. PLoS Pathog. 2017;13:e1006438.

122. Hiyoshi H, Kodama T, Saito K, Gotoh K, Matsuda S, Akeda Y, Honda T, lida $\mathrm{T}$. VopV, an F-actin-binding type III secretion effector, is required for Vibrio parahaemolyticus-induced enterotoxicity. Cell Host Microbe. 2011;10:4019

123. Zhou X, Massol RH, Nakamura F, Chen X, Gewurz BE, Davis BM, Lencer WI, Waldor MK. Remodeling of the intestinal brush border underlies adhesion and virulence of an enteric pathogen. mBio. 2014;5:e01639-14.

124. Chaand M, Miller KA, Sofia MK, Schlesener C, Weaver JW, Sood V Dziejman $M$. Type three secretion system island encoded proteins required for colonization by non-01/non-0139 serogroup Vibrio cholerae. Infect Immun. 2015;83:2862-9.

125. Calder T, Kinch LN, Fernandez J, Salomon D, Grishin NV, Orth K. Vibrio type III effector VPA1380 is related to the cysteine protease domain of large bacterial toxins. PloS One. 2014;9:e104387.

126. Izutsu K, Kurokawa K, Tashiro K, Kuhara S, Hayashi T, Honda T, lida T. Comparative genomic analysis using microarray demonstrates a strong correlation between the presence of the 80-kilobase pathogenicity island and pathogenicity in Kanagawa phenomenon-positive Vibrio parahaemolyticus strains. Infect Immun. 2008;76:1016-23. 
127. Boyd EF, Cohen AL, Naughton LM, Ussery DW, Binnewies T, Stine OC, Parent MA. Molecular analysis of the emergence of pandemic Vibrio parahaemolyticus. BMC Microbiol. 2008;8:110.

128. Yu Y, Yang H, Li J, Zhang P, Wu B, Zhu B, Zhang Y, Fang W. Putative type $\mathrm{VI}$ secretion systems of Vibrio parahaemolyticus contribute to adhesion to cultured cell monolayers. Arch Microbiol. 2012;194:827-35.

129. Ceccarelli D, Hasan NA, Huq A, Colwell RR. Distribution and dynamics of epidemic and pandemic Vibrio parahaemolyticus virulence factors. Front Cell Infect Microbiol. 2013;3:97.

130. Salomon D, Gonzalez H, Updegraff BL, Orth K. Vibrio parahaemolyticus type $\mathrm{VI}$ secretion system 1 is activated in marine conditions to target bacteria, and is differentially regulated from system 2. PloS One. 2013;8:e61086.

131. McCarter L. The multiple identities of Vibrio parahaemolyticus. J Mol Microbiol Biotechnol. 1999;1:51-7.

132. lida T, Suthienkul O, Park KS, Tang GQ, Yamamoto RK, Ishibashi M, Yamamoto K, Honda T. Evidence for genetic linkage between the ure and trh genes in Vibrio parahaemolyticus. J Med Microbiol. 1997;46:639-45.

133. Cai Y, Ni Y. Purification, characterization, and pathogenicity of urease produced by Vibrio parahaemolyticus. J Clin Lab Anal. 1996;10:70-3.

134. Osawa R, Okitsu T, Morozumi H, Yamai S. Occurrence of urease-positive Vibrio parahaemolyticus in Kanagawa, Japan, with specific reference to presence of thermostable direct hemolysin (TDH) and the TDH-relatedhemolysin genes. Appl Environ Microbiol. 1996;62:725-7.

135. Levin RE. Vibrio parahaemolyticus, a notably lethal human pathogen derived from seafood: a review of its pathogenicity, characteristics, subspecies characterization, and molecular methods of detection. Food Biotechnol. 2006;20:93-128.

136. Chiou CS, Hsu SY, Chiu SI, Wang TK, Chao CS. Vibrio parahaemolyticus serovar 03:K6 as cause of unusually high incidence of food-borne disease outbreaks in Taiwan from 1996 to 1999. J Clin Microbiol. 2000;38:4621-5.

137. Vuddhakul V, Chowdhury A, Laohaprertthisan V, Pungrasamee $P$, Patararungrong N, Thianmontri $P$, Ishibashi $M$, Matsumoto $C$, Nishibuchi $\mathrm{M}$. Isolation of a pandemic 03:K6 clone of a Vibrio parahaemolyticus strain from environmental and clinical sources in Thailand. Appl Environ Microbiol. 2000;66:2685-9.

138. González-Escalona N, Cachicas V, Acevedo C, Rioseco ML, Vergara JA, Cabello F, Romero J, Espejo RT. Vibrio parahaemolyticus diarrhea, Chile, 1998 and 2004. Emerg Infect Dis. 2005;11:129-31.

139. Okuda J, Ishibashi M, Hayakawa E, Nishino T, Takeda Y, Mukhopadhyay AK, Garg S, Bhattacharya SK, Nair GB, Nishibuchi M. Emergence of a unique 03:K6 clone of Vibrio parahaemolyticus in Calcutta, India, and isolation of strains from the same clonal group from Southeast Asian travelers arriving in Japan. J Clin Microbiol. 1997;35:3150-5.

140. Daniels NA, Ray B, Easton A, Marano N, Kahn E, McShan AL 2nd, Del Rosario L, Baldwin T, Kingsley MA, Puhr ND, Wells JG, Angulo FJ. Emergence of a new Vibrio parahaemolyticus serotype in raw oysters: a prevention quandary. JAMA. 2000;284:1541-5.

141. Centers for Disease Control and Prevention (CDC). Outbreak of Vibrio parahaemolyticus infection associated with eating raw oysters and clams harvested from Long Island Sound--Connecticut, New Jersey, and New York, 1998. MMWR Morb Mortal Wkly Rep. 1999;48:48-51.

142. Hurley CC, Quirke A, Reen FJ, Boyd EF. Four genomic islands that mark post-1995 pandemic Vibrio parahaemolyticus isolates. BMC Genomics. 2006;7:104.

143. Nishioka $T$, Kamruzzaman $M$, Nishibuchi $M$, Satta $Y$. On the origin and function of an insertion element VPal-1 specific to post-1995 pandemic Vibrio parahaemolyticus strains. Genes Genet Syst. 2008;83:101-10.

144. Chao G, Jiao X, Zhou X, Yang Z, Huang J, Pan Z, Zhou L, Oian X. Serodiversity, pandemic 03:K6 clone, molecular typing, and antibiotic susceptibility of foodborne and clinical Vibrio parahaemolyticus isolates in Jiangsu, China. Foodborne Pathog Dis. 2009;6:1021-8.
145. Espejo RT, Garcia K, Plaza N. Insight into the origin and evolution of the Vibrio parahaemolyticus pandemic strain. Front Microbiol. 2017;8:1397.

146. Garcia K, Bastías R, Higuera G, Torres R, Mellado A, Uribe P, Espejo RT. Rise and fall of pandemic Vibrio parahaemolyticus serotype 03:K6 in southern Chile. Environ Microbiol. 2013;15:527-34.

147. Meparambu Prabhakaran D, Ramamurthy T, Thomas S. Genetic and virulence characterisation of Vibrio parahaemolyticus isolated from Indian coast. BMC Microbiol. 2020;20:62.

148. Caburlotto G, Haley BJ, Lleò MM, Huq A, Colwell RR. Serodiversity and ecological distribution of Vibrio parahaemolyticus in the Venetian Lagoon, Northeast Italy. Environ Microbiol Rep. 2010;2:151-7.

149. Chen $X$, Li Y, Yao W, Wu T, Zhu Q, Zhang Y, Ye H, Wang R, Zheng S, Yu F, Chen W, Zhu Z, Mao L, Hu Q, Tang Z, Chen H, Liu Y, Chen Y. A new emerging serotype of Vibrio parahaemolyticus in China is rapidly becoming the main epidemic strain. Clin Microbiol Infect. 2020;26:644.

150. Hu Y, Li F, Zheng Y, Jiao X, Guo L. Isolation, Molecular Characterization and Antibiotic Susceptibility Pattern of Vibrio parahaemolyticus from Aquatic Products in the Southern Fujian Coast, China. J Microbiol Biotechnol. 2020;30:856-67.

151. Mog M, Ngasotter S, Tesia S, Waikhom D, Panda PS, Sharma S, Varshney S. Problems of antibiotic resistance associated with oxytetracycline use in aquaculture: A review. J Entomol Zool Stud. 2020;8:1075-82.

152. Mazel D, Davies J. Antibiotic resistance in microbes. Cell Mol Life Sci. 1999;56:742-54.

153. Cabello FC. Heavy use of prophylactic antibiotics in aquaculture: a growing problem for human and animal health and for the environment. Environ Microbiol. 2006;8:1137-44.

154. Allen HK, Donato J, Wang HH, Cloud-Hansen KA, Davies J, Handelsman J. Call of the wild: antibiotic resistance genes in natural environments. Nat Rev Microbiol. 2010;8:251-9.

155. Oliver JD. Vibrio vulnificus. In: Thompson FL, Austin B, Swings J (ed). The biology of Vibrios. Washington DC: ASM Press, 2006:349-66.

156. Elmahdi S, DaSilva LV, Parveen S. Antibiotic resistance of Vibrio parahaemolyticus and Vibrio vulnificus in various countries: a review. Food Microbiol. 2016;57:128-34.

157. Navaneeth KA, Bhuvaneswari T, Rajan JJS, Alavandi SV, Vijayan KK, Otta SK. Characterization of Vibrio parahaemolyticus isolates from shrimp farms of Southeast coast of India with special reference to Acute Hepatopancreatic Necrosis Disease (AHPND) status. Aquaculture. 2020;518:734813.

158. Sudha , Mridula $C$, Silvester R, Hatha AAM. Prevalence and antibiotic resistance of pathogenic Vibrios in shellfishes from Cochin market. Indian J Geo-Mar Sci. 2014;43:815-24.

159. Vaseeharan $B$, Ramasamy $P$, Murugan $T$, Chen JC. In vitro susceptibility of antibiotics against Vibrio spp. and Aeromonas spp. isolated from Penaeus monodon hatcheries and ponds. Int J Antimicrob Agents. 2005;26:285-91.

160. Jeong HW, Kim JA, Jeon SJ, Choi SS, Kim MK, Yi HJ, Cho SJ, Kim IY, Chon JW, Kim DH, Bae D, Kim H, Seo KH. Prevalence, antibiotic-resistance, and virulence characteristics of Vibrio parahaemolyticus in restaurant fish tanks in Seoul, South Korea. Foodborne Pathog Dis. 2020;17:209-14.

161. Lee Y, Choi Y, Lee S, Lee H, Kim S, Ha J, Lee J, Oh H, Kim Y, Yoon Y. Occurrence of pathogenic Vibrio parahaemolyticus in seafood distribution channels and their antibiotic resistance profiles in S. Korea. Lett Appl Microbiol. 2019;68:128-33.

162. Ottaviani D, Leoni F, Talevi G, Masini L, Santarelli S, Rocchegiani E, Susini F, Montagna C, Monno R, D'Annibale L, Manso E, Oliva M, Pazzani C. Extensive investigation of antimicrobial resistance in Vibrio parahaemolyticus from shellfish and clinical sources, Italy. Int J Antimicrob Agents. 2013;2:191-3.

163. Labella A, Gennari M, Ghidini V, Trento I, Manfrin A, Borrego JJ, Lleo MM. High incidence of antibiotic multi-resistant bacteria in coastal areas dedicated to fish farming. Mar Pollut Bull. 2013;70:197-203. 
164. Jeamsripong S, Khant W, Chuanchuen R. Distribution of phenotypic and genotypic antimicrobial resistance and virulence genes in Vibrio parahaemolyticus isolated from cultivated oysters and estuarine water. FEMS Microbiol Ecol. 2020;96:fiaa081.

165. Liu F, Guan W, Alam MJ, Shen Z, Zhang S, Li L, Shinoda S, Shi L. Pulsed-field gel electrophoresis typing of multidrug-resistant Vibrio parahaemolyticus isolated from various sources of seafood. J Health Sci. 2009;55:783-9.

166. de Melo LM, Almeida D, Hofer E, Dos Reis CM, Theophilo GN, Santos AF, Vieira RH. Antibiotic resistance of Vibrio parahaemolyticus isolated from pond-reared Litopenaeus vannamei marketed in Natal, Brazil. Braz J Microbiol. 2011;42:1463-9.

167. Tan CW, Rukayadi Y, Hasan H, Thung TY, Lee E, Rollon WD, Hara H, Kayali AY, Nishibuchi M, Radu S. Prevalence and antibiotic resistance patterns of Vibrio parahaemolyticus isolated from different types of seafood in Selangor, Malaysia. Saudi J Biol Sci. 2020;27:1602-8.

168. Beshiru A, Okareh OT, Okoh Al, Igbinosa EO. Detection of antibiotic resistance and virulence genes of Vibrio strains isolated from ready-to-eat shrimps in Delta and Edo States, Nigeria. J Appl Microbiol. 2020;129:17-36.

169. Ahmed HA, El Bayomi RM, Hussein MA, Khedr MHE, Abo Remela EM, ElAshram AMM. Molecular characterization, antibiotic resistance pattern and biofilm formation of Vibrio parahaemolyticus and V. cholerae isolated from crustaceans and humans. Int J Food Microbiol. 2018;274:31-7.

170. Ghenem L, Elhadi N. Isolation, molecular characterization, and antibiotic resistance patterns of Vibrio parahaemolyticus isolated from coastal water in the Eastern Province of Saudi Arabia. J Water Health. 2018;16:57-69.
171. Letchumanan V, Chan KG, Lee LH. Vibrio parahaemolyticus: a review on the pathogenesis, prevalence, and advance molecular identification techniques. Front Microbiol. 2014;5:705.

172. Kim DH, Rajapaksha LGTG, Gunasekara ACWR, Wimalasena SHMP, Pathirana HNKS, Kim SR, Seo BJ, Heo GJ, Shin GW. Phylogenetic relationships and antibiotic resistance of Vibrio parahaemolyticus isolates related to acute hepatopancreatic necrosis disease in Korea. Aquaculture. 2021;545:737253.

173. Parthasarathy S, Das SC, Kumar A, Chowdhury G, Miyoshi SI, Dutta S, Mukhopadhyay AK. Molecular characterization and antibiotic resistance of Vibrio parahaemolyticus from Indian oyster and their probable implication in food chain. World J Microbiol Biotechnol. 2021;37:145.

174. Mok JS, Cho SR, Park YJ, Jo MR, Ha KS, Kim PH, Kim MJ. Distribution and antimicrobial resistance of Vibrio parahaemolyticus isolated from fish and shrimp aquaculture farms along the Korean coast. Mar Pollut Bull. 2021;171:112785.

175. Ali $S$, Hossain $M, A z a d A B$, Siddique $A B$, Moniruzzaman $M$, Ahmed $M A$, Amin MB, Islam MS, Rahman MM, Mondal D, Mahmud ZH. Diversity of Vibrio parahaemolyticus in marine fishes of Bangladesh. J Appl Microbiol. 2021;131:2539-51.

176. da Silva LV, Ossai S, Chigbu P, Parveen S. Antimicrobial and Genetic Profiles of Vibrio vulnificus and Vibrio parahaemolyticus Isolated From the Maryland Coastal Bays, United States. Front Microbiol. 2021;12:676249. 